\begin{tabular}{|c|c|c|}
\hline$w^{4}+2-8.99$ & ENGINEERING DATA TRANSMITTAL & $\begin{array}{r}\text { Page } 1 \text { of } \frac{1}{1} \\
\text { 1. EDT } 627464\end{array}$ \\
\hline
\end{tabular}

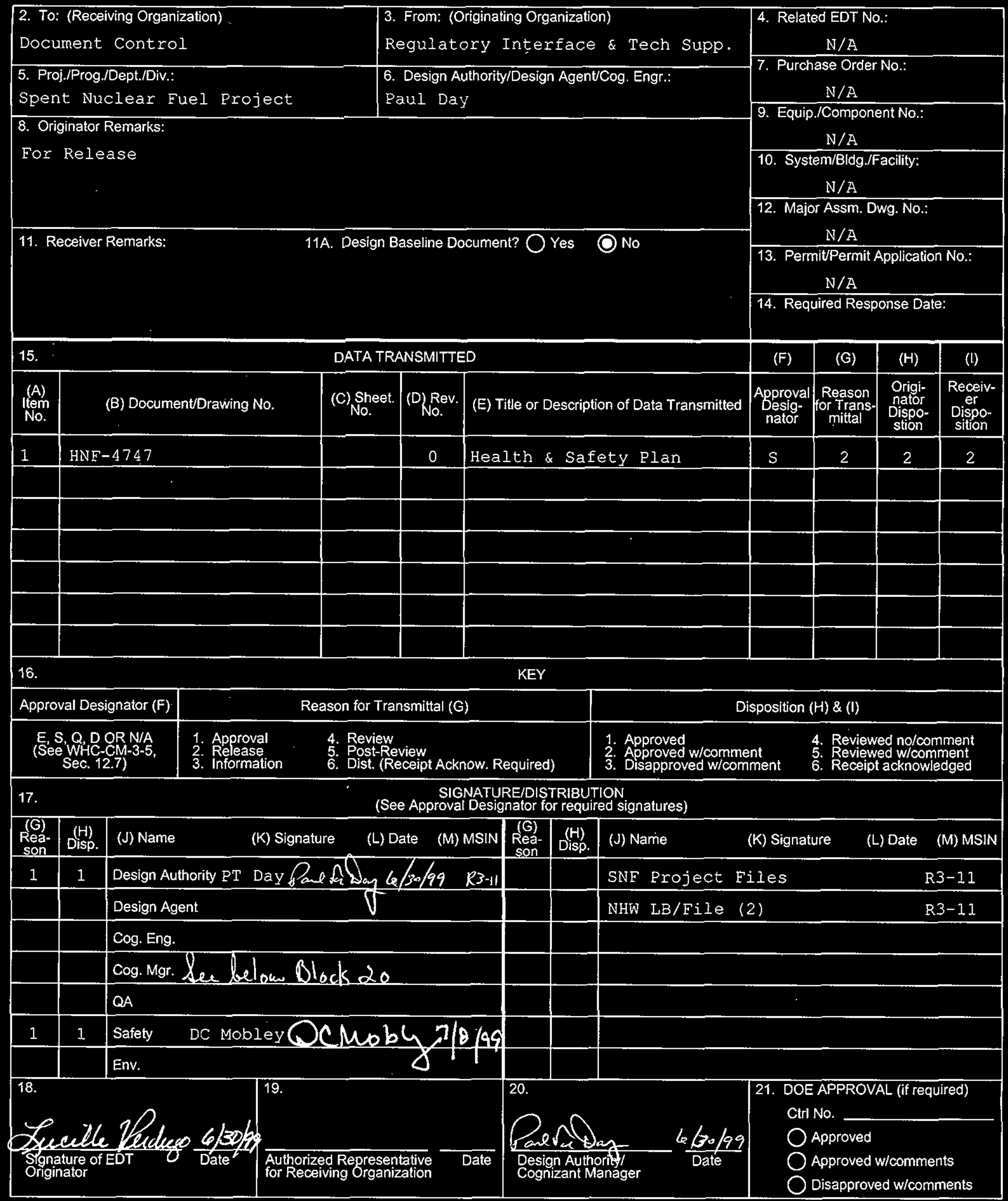




\section{K Basins Interim Remedial Action Health and Safety Plan}

Paul T. Day

Richland, WA 99352

U.S. Department of Energy Contract DE-AC06-96RL13200

$\begin{array}{lll}\text { EDT/ECN: } 627464 & \text { UC: } 2000 \\ \text { Org Code: } & 41100 & \text { Charge Code: } 105346 \text { A000 } \\ \text { B\&R Code: } & \text { Ew3 } 130000 & \text { Total Pages: } 62\end{array}$

Key Words: Health and Safety Plan, $K$ Basins, Hazard Mitigation, Hazard Identification, Training, Medical Surveillance, Monitoring, CERCLA, OSHA

Abstract: The $\mathrm{K}$ Basins Interim Remedial Action Health and Safety Plan addresses the requirements of the Comprehensive Environmental Response, Compensation and Liability Act (CERCLA), as they apply to the CERCLA work that will take place at the $\mathrm{K}$ East and $\mathrm{K}$ West Basins. The provisions of this plan become effective on the date the U.S. Environmental Protection Agency issues the Record of Decision for the K Basins Interim Remedial Action, cuxxently planned in late August 1999.

TRADEMARK DISCLAIMER. Reference herein to any specific commercial product, process, or service by trade name, trademark, manufacturer, or otherwise, does not necessarily constitute or imply its endorsement, recommendation, or favoring by the United States Government or any agency thereof or its contractors or subcontractors.

Printed in the United States of America. To obtain copies of this document, contact: Document Control Services, P.O. Box 950, Mailstop H6-08, Richland WA 99352, Phone (509) 372-2420; Fax (509) 376-4989.
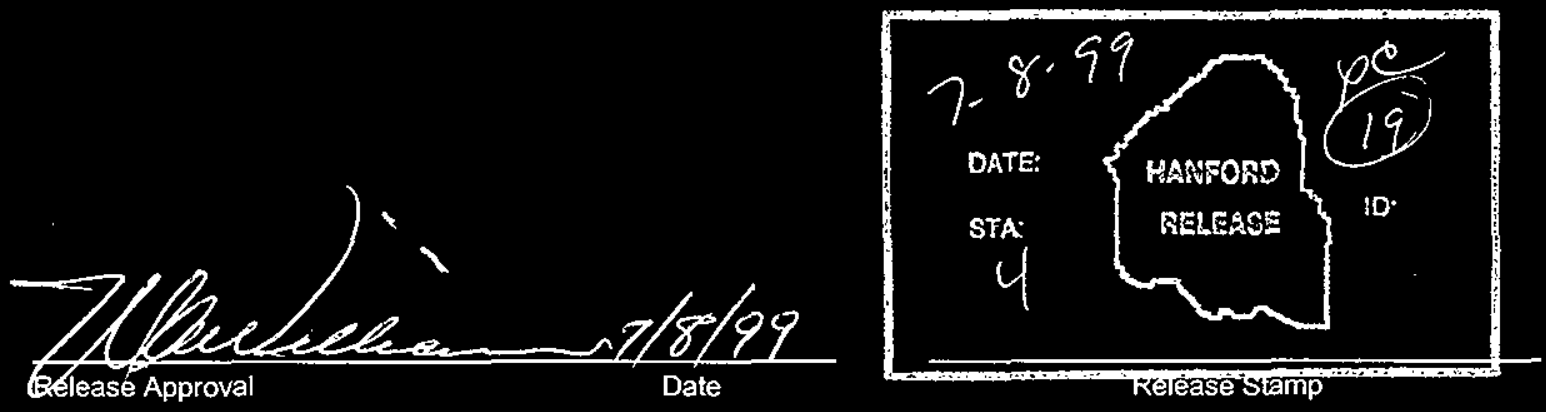

\section{Approved For Public Release}




\section{K BASINS INTERIM REMEDIAL ACTION}

\section{HEALTH AND SAFETY PLAN}

Fluor Daniel Hanford, Inc.

Spent Nuclear Fuel Project

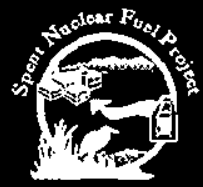

HNF-4747

Rev. 0

June 30, 1999 


\begin{tabular}{|c|c|r|}
\hline & DOCUMENT: & HNF-4747 \\
REVISION: & 0 \\
DATE: & PAGE: & 06/30/99 \\
\hline
\end{tabular}

\section{TABLE OF CONTENTS}

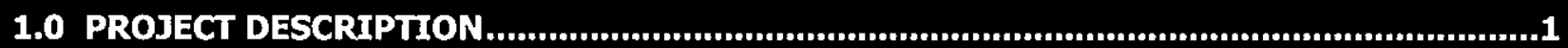

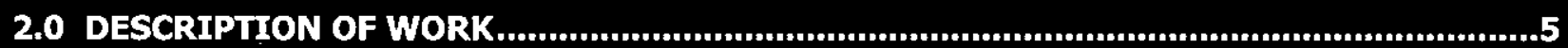

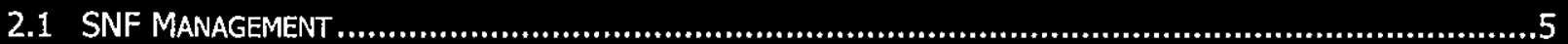

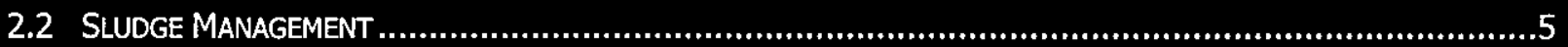

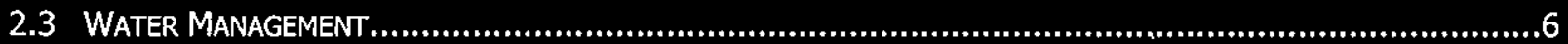

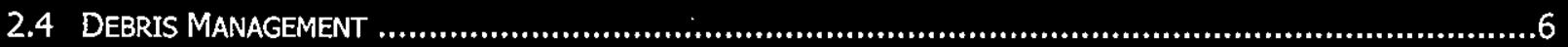

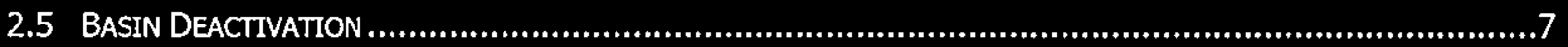

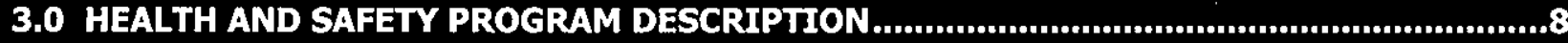

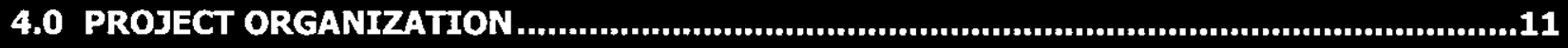

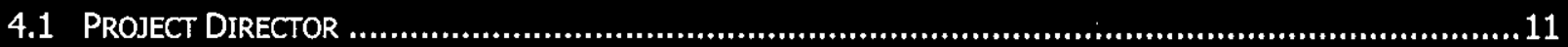

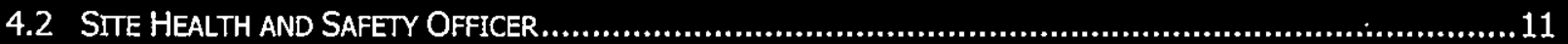

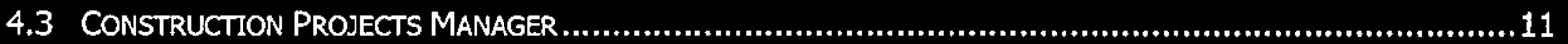

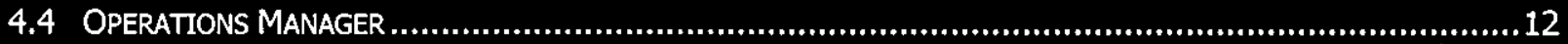

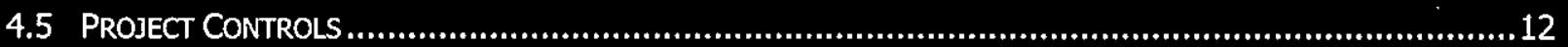

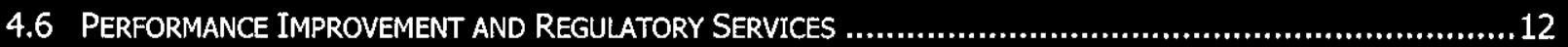

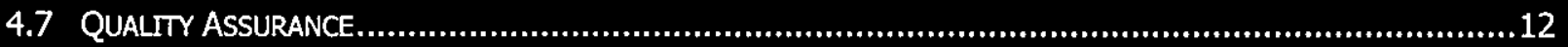

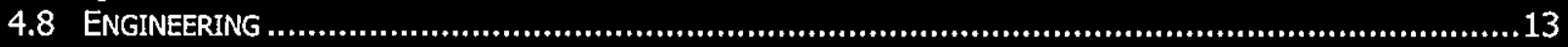

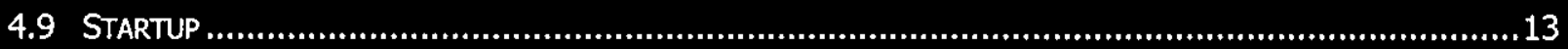

4.10 RADIOLOGICAL CONTROL...........................................................................................

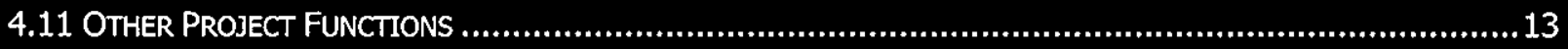

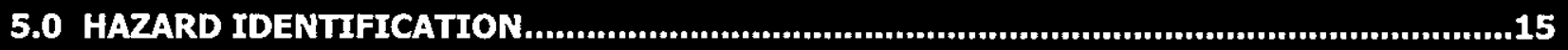

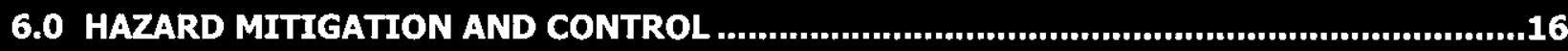

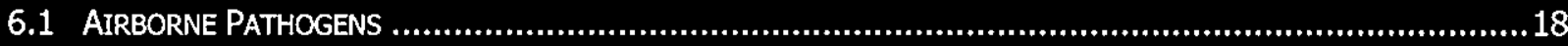

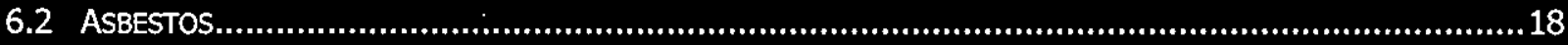

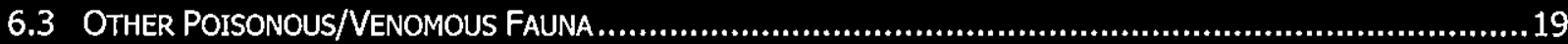

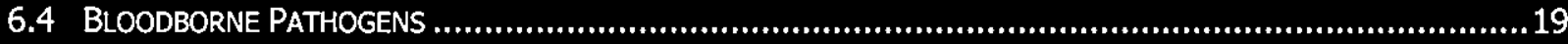

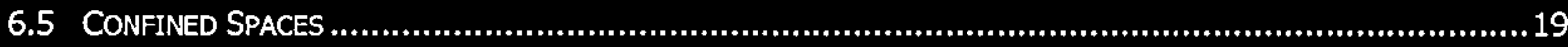

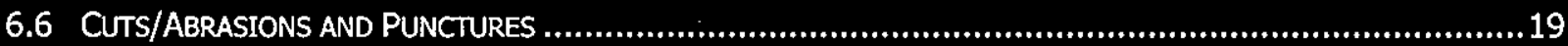

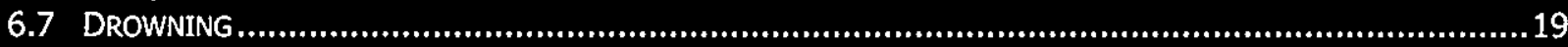

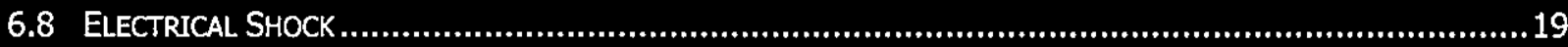

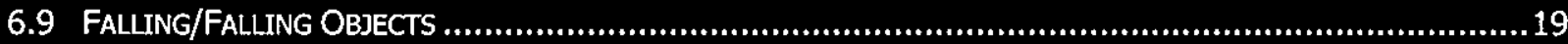

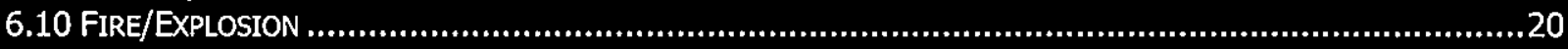

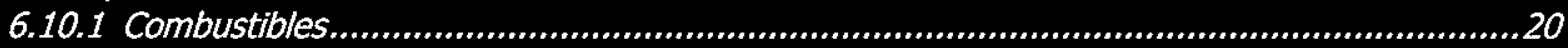

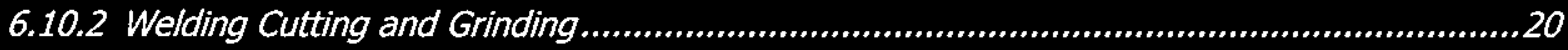

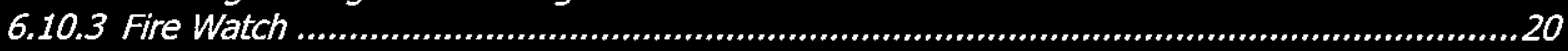

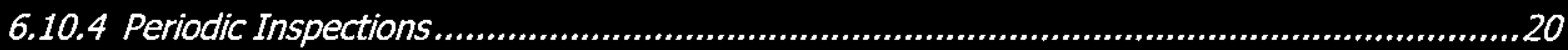

6.10 .5 Portable Heaters...........................................................................................20

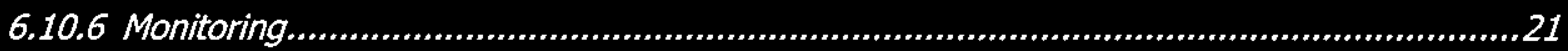

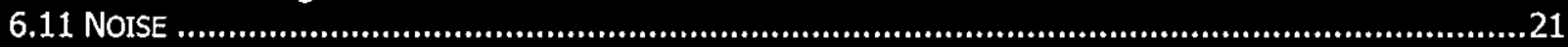

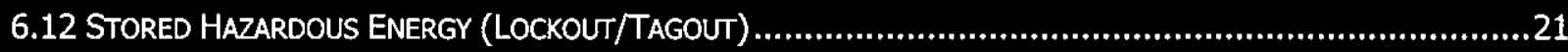

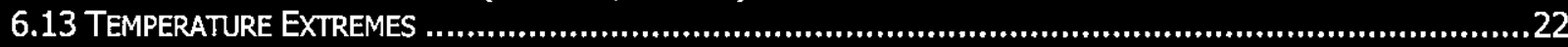

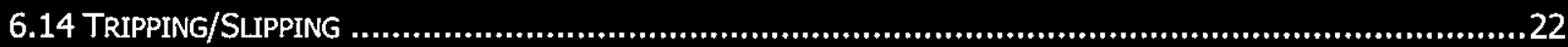

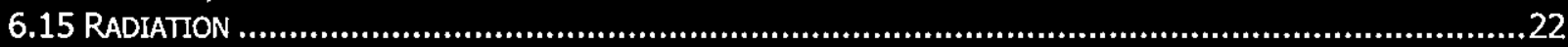

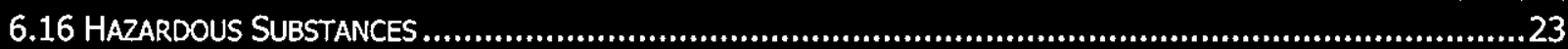

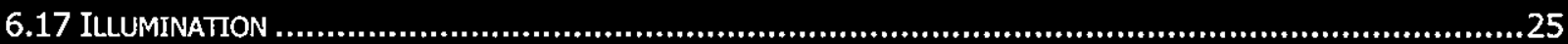




\begin{tabular}{|c|c|c|}
\hline & DOCUMENT: & HNF-4747 \\
REVISION: & 0 \\
DATE: & $06 / 30 / 99$ \\
PAGE: & II \\
\hline
\end{tabular}

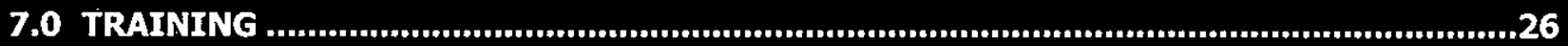

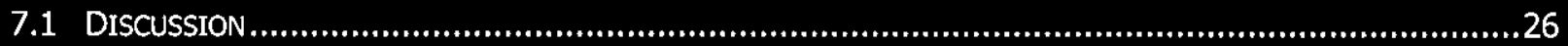

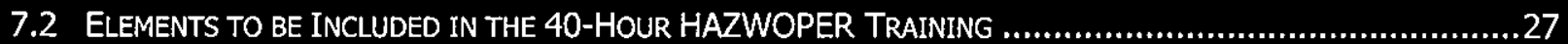

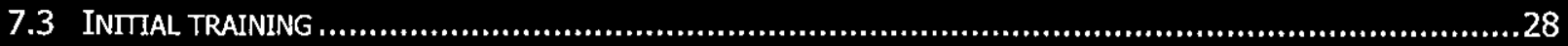

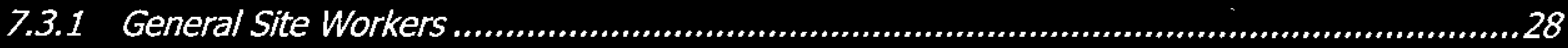

7.3.2 . Infrequent Workers.................................................................................... 28

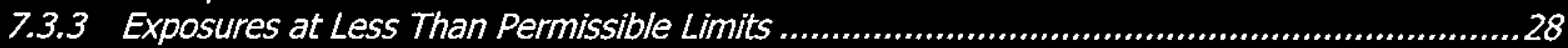

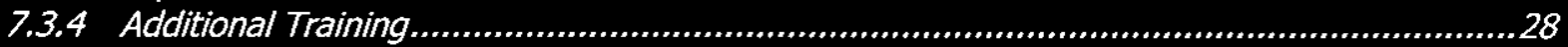

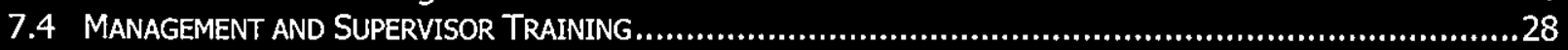

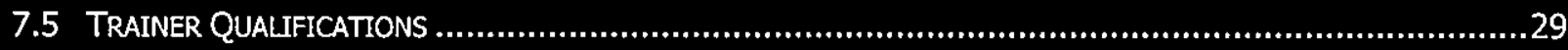

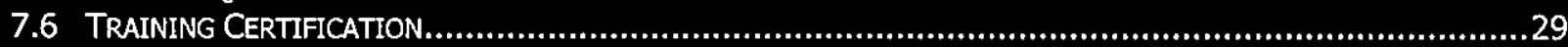

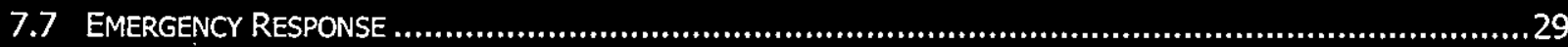

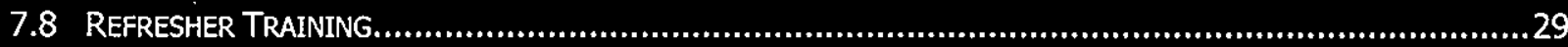

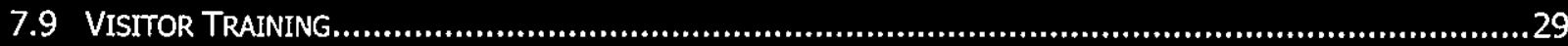

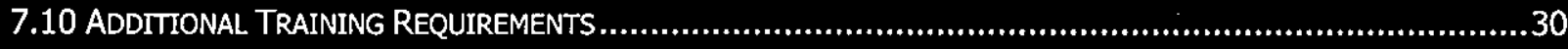

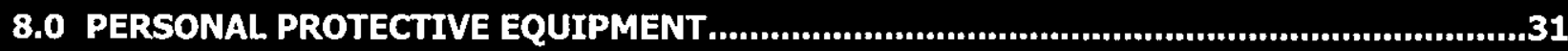

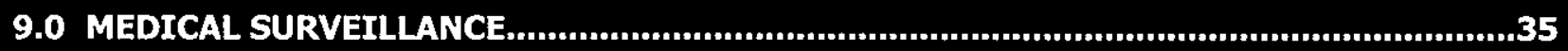

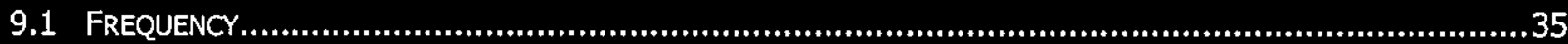

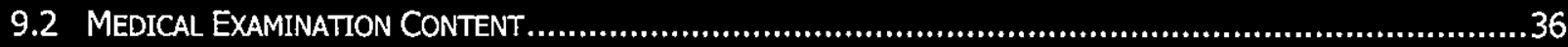

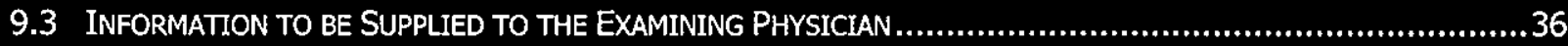

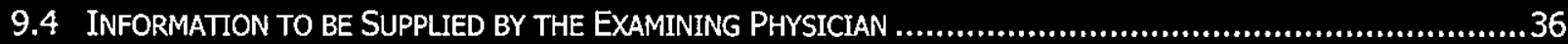

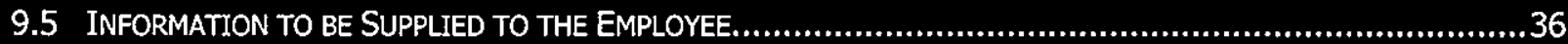

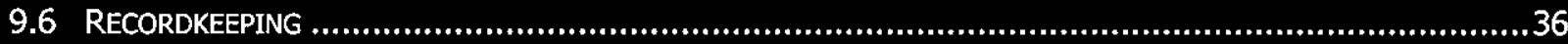

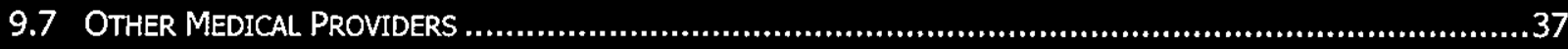

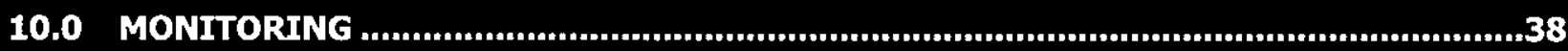

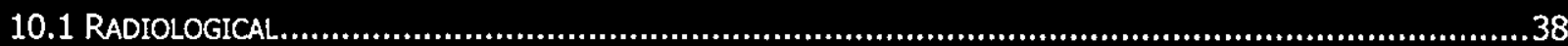

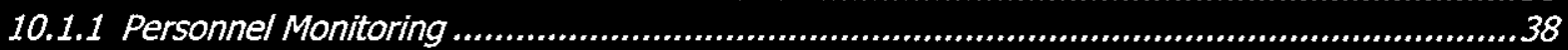

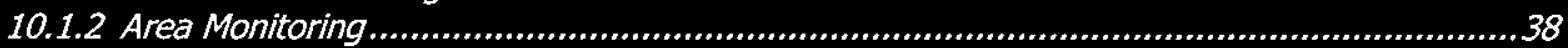

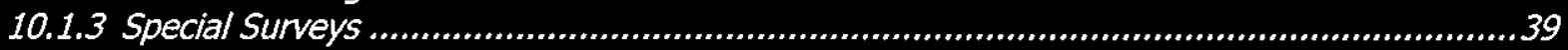

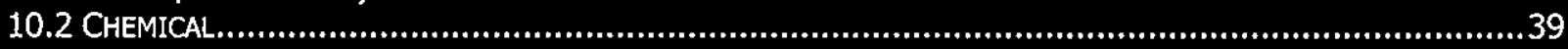

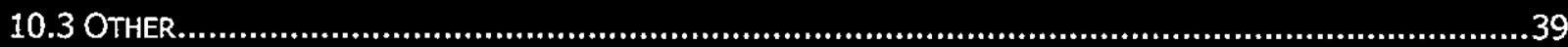

11.0 SITE CONTROL

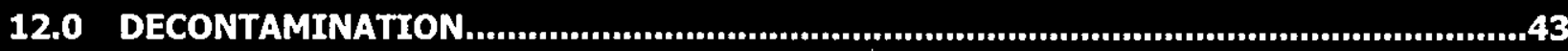

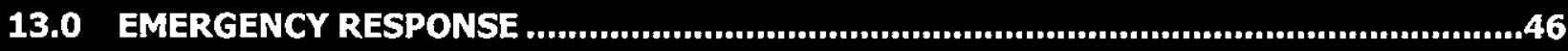

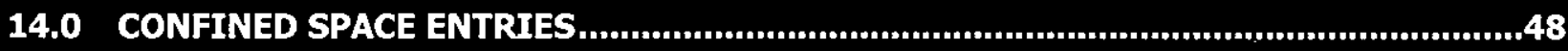

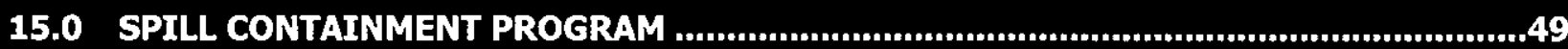

16.0 PRE-ENTRY BRIEFINGS $\ldots \ldots \ldots \ldots$

17.0 HAZARD COMMUNICATION PROGRAM ................................................................51

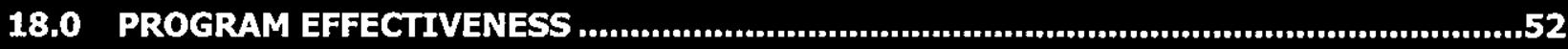

19.0 REFERENCES 


\begin{tabular}{|c|c|rr|}
\hline & & DOCUMENT: & HNF-4747 \\
REVISION: & 0 \\
DATE: & $06 / 30 / 99$ \\
PAGE: & III \\
\hline
\end{tabular}

TABLES

Table 3-1: $\quad$ AJHA/ISMS PROGRAM ELEMENTS AND OBJECTIVES 9

Table 6-1 HAZARDS IDENTIFICATION $\quad 16$

$\begin{array}{lll}\text { Table 6-11 PERMISSIBLE NOISE EXPOSURES } & 21\end{array}$

Table 6-16 CHEMICAL MANAGEMENT PROGRAM ATTRIBUTES 23

$\begin{array}{lll}\text { Table 7-1 HAZWOPER TRAINING REQUIREMENTS } & 27\end{array}$

Table 8-1 PERSONAL PROTECTIVE EQUIPMENT ENSEMBLES

Table 12-1 SUMMARY OF CONTAMINATION VALUES $\quad 45$

Table 13-1 EMERGENCY CONTACT INFORMATION $\quad 47$ 


\begin{tabular}{|c|c|rr|}
\hline & DOCUMENT: & HNF-4747 \\
REVISION: & 0 \\
DATE: & $06 / 30 / 99$ \\
PAGE: & & IV \\
\hline
\end{tabular}

FIGURES

$\begin{array}{lll}\text { Figure 1-1 HANFORD LOCATION MAP } & 3\end{array}$

$\begin{array}{lll}\text { Figure 1-2 HANFORD MAP } & 4\end{array}$

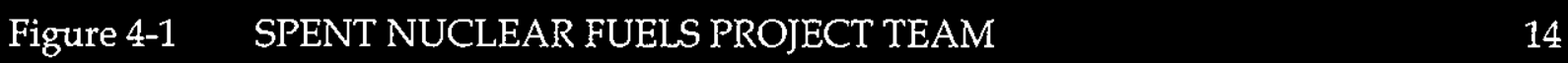

Figure 13-1 HANFORD SITE EMERGENCY INSTRUCTIONS 47 


\begin{tabular}{|c|c|r|}
\hline & DOCUMENT: & HNF-4747 \\
REVISION: & 0 \\
DATE: & $06 / 30 / 99$ \\
PAGE: & K BASINS INTERIM REMEDIAL ACTION \\
\hline
\end{tabular}

\section{ACRONYMS}

\begin{tabular}{|c|c|}
\hline Ac & Actinium \\
\hline ACGIH & American Conference of Governmental Industrial Hygienists \\
\hline $\mathrm{ACM}$ & Asbestos Containing Materials \\
\hline AJHA & Automated Job Hazards Analysis \\
\hline ALARA & As Low As Reasonably Achievable \\
\hline BEP & Building Emergency Plan \\
\hline BED & Building Emergency Director \\
\hline CERCLA & $\begin{array}{l}\text { Comprehensive Environmental Response, Compensation, and Liability Act } \\
\text { of } 1980\end{array}$ \\
\hline CFR & Code of Federal Regulations \\
\hline CGI & Combustible Gas Indicator \\
\hline $\mathrm{cm}^{2}$ & square centimeter \\
\hline $\mathrm{cm}^{3}$ & cubic centimeter \\
\hline CMP & Chemical Management Plan \\
\hline CMS & Chemical Management System \\
\hline CPR & Cardiopulmonary Resuscitation \\
\hline CVD & Cold Vacuum Drying \\
\hline $\mathrm{DAC}$ & Derived Air Concentration \\
\hline $\mathrm{dB}$ & decibel \\
\hline $\mathrm{dBA}$ & decibels on the " $A$ " weighting scale \\
\hline DOE & U.S. Department of Energy \\
\hline dpm & Disintegrations Per Minute \\
\hline E\}TA & Employee Job Task Analysis \\
\hline EPA & Environmental Protection Agency \\
\hline ETF & Effluent Treatment Facility \\
\hline $\mathrm{eV}$ & electron volt \\
\hline $\mathrm{FDH}$ & Fluor Daniel Hanford, Inc. \\
\hline GFCI & Ground Fault Circuit Interrupter \\
\hline HAMMER & Hazardous Materials Management and Emergency Response \\
\hline HASP & Health And Safety Plan \\
\hline HAZWOPER & Hazardous Waste Operations and Emergency Response \\
\hline HEHF & Hanford Environmental Health Foundation \\
\hline HGET & Hanford General Employee Training \\
\hline HSRCM & Hanford Site Radiological Control Manual \\
\hline I & Iodine \\
\hline IWTS & Integrated Water Treatment System \\
\hline K East & $100 \mathrm{~K}$ Reactor - East \\
\hline K West & $100 \mathrm{~K}$ Reactor - West \\
\hline MSA & Management Self-Assessment \\
\hline $\mathrm{MCO}$ & Multi-Canister Overpack \\
\hline mrem & millirem \\
\hline MSDS & Material Safety Data Sheet \\
\hline NIOSH & National Institute of Occupational Safety and Health \\
\hline
\end{tabular}




\begin{tabular}{|c|c|c|}
\hline & DOCUMENT: & HNF-4747 \\
REVISION: & 0 \\
DATE: & $06 / 30 / 99$ \\
PAGE: & K BASINS INTERIM REMEDIAL ACTION & \\
\hline
\end{tabular}

\section{ACRONYMS - Continued}

$\begin{array}{ll}\text { ORR } & \text { Operational Readiness Review } \\ \text { OSHA } & \text { Occupational Safety and Health Administration } \\ \text { PEL } & \text { Permissible Exposure Limit } \\ \text { PEP } & \text { Project Execution Plan } \\ \text { PFD } & \text { Personal Flotation Device } \\ \text { PHMC } & \text { Project Hanford Management Contract } \\ \text { PPE } & \text { Personal Protective Equipment } \\ \text { QA } & \text { Quality Assurance } \\ \text { Ra } & \text { Radium } \\ \text { RCT } & \text { Radiological Control Technician } \\ \text { rem } & \text { Roentgen Equivalent Man } \\ \text { RWP } & \text { Radiation Work Permit } \\ \text { SARA } & \text { Superfund Amendments Reauthorization Act of 1986 } \\ \text { SCBA } & \text { Self Contained Breathing Apparatus } \\ \text { SHSO } & \text { Site Health and Safety Officer } \\ \text { SME } & \text { Subject Matter Expert } \\ \text { SNF } & \text { Spent Nuclear Fuel } \\ \text { Sr } & \text { Strontium } \\ \text { Th } & \text { Thorium } \\ \text { TLV } & \text { Threshold Limit Value } \\ \text { TWA } & \text { Time Weighted Average } \\ \text { U } & \text { Uranium } \\ \text { UL } & \text { Underwriters' Laboratories } \\ & \end{array}$




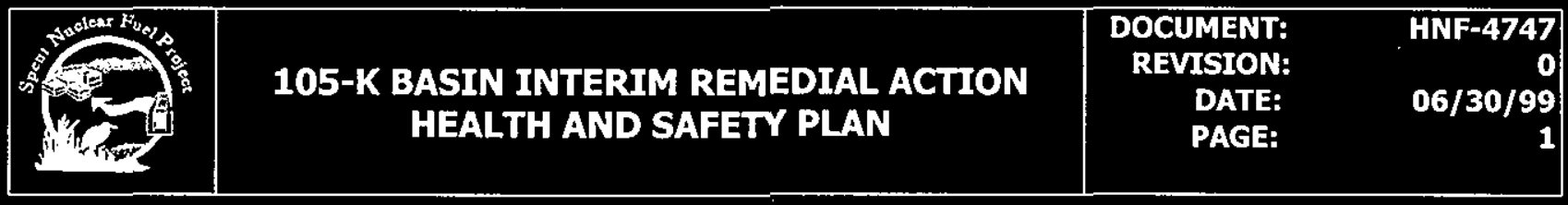

\subsection{PROJECT DESCRIPTION}

The Hanford Site is a 1,450 square kilometer (560 square mile) Federal facility located in southeastern Washington State along the Columbia River. The Hanford Site operated from 1943 to 1990, producing nuclear materials for the nation's defense. In July 1989, the Hanford Site was listed on the National Priorities List under the Comprehensive Environmental Response, Compensation, and Liability Act of 1980 (CERCLA), as amended by the Superfund Amendments and . Reauthorization Act of 1986 (SARA). The Hanford Site was divided and listed as four National Priorities List sites: the 100 Area, the 200 Area, the 300 Area, and the 1100 Area. The K Reactor complex is comprised of two deactivated production reactors ( $\mathrm{K}$ East and $\mathrm{K}$ West), and their respective support facilities. The location of the Hanford Site, relative to North America, is shown in Figure 1-1. The location of the K Reactor complex in the 100 Area, relative to the Hanford Site is shown in Figure 1-2.

Both of the K Reactors were constructed in the early 1950's, and operated from the mid-1950's until 1970 (K West) and 1971 (KE). Most of the Spent Nuclear Fuel (SNF) discharged from the $K$ Reactors and stored in the associated basins was removed when the reactors were shut down. The basins at each reactor were subsequently used to store SNF from the N Reactor, starting in 1975 for K East and 1981 for K West. In 1992, the decision was made to deactivate the facility where the SNF was being processed. This left approximately 2,100 metric tons $(2,300$ tons) of SNF in the $\mathrm{K}$ Basins with no means for reprocessing.

Each basin measures 38 meters ( 125 feet) in length by 20 meters ( 67 feet) in width by 6 meters (20 feet) deep, and is comprised of unlined and uncovered concrete construction housed inside buildings. The basins contain SNF $(1,150$ metric tons $[1,260$ tons] in K East, and 953 metric tons [1,050 tons] in K West), sludge contaminated with SNF corrosion products, approximately 4,900,000 liters $(1,300,000$ gallons) of water in each basin, and miscellaneous debris. Each basin has six "pits" appended at its periphery (two load-out pits, an elevator pit, a Weasel pit, a Tech View pit, and a transfer pit). The sludge inventory has been estimated for each of these pits (DOE98A). The principal constituents of the sludge are iron, silicon, aluminum, radioactive materials, and smaller quantities of organic ion exchange resins, Zeolite, zircalloy, and polychlorinated biphenyls. The principal constituents of the SNF, and the radioactive materials present in the sludge, are isotopes of strontium, cesium, uranium, americium, and plutonium. Radioactive materials surface contamination is present in the $\mathrm{K}$ East Building and, to a lessor extent, in the $\mathrm{K}$ West Building.

The SNF Project, under the Hanford Federal Facility Agreement and Consent Order (Tri-Party Agreement), will be managed under CERCLA, with the U. S. Environmental Protection Agency (EPA) as the lead regulatory agency. The EPA plans to issue the CERCLA Record of Decision by June 30, 1999, at which time the SNF Project will officially be regulated under CERCLA. 


\begin{tabular}{|c|c|c|c|}
\hline 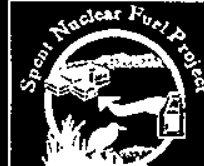 & $\begin{array}{l}\text { K BASINS INTERIM REMEDIAL ACTION } \\
\text { HEALTH AND SAFETY PLAN }\end{array}$ & $\begin{array}{r}\text { DOCUMENT: } \\
\text { REVISION: } \\
\text { DATE: } \\
\text { PAGE: }\end{array}$ & $\begin{array}{r}\text { HNF-4747 } \\
0 \\
06 / 30 / 99 \\
2\end{array}$ \\
\hline
\end{tabular}

The scope of the K Basins CERCLA Interim Remedial Action Project includes removal of the SNF, debris, and water from the basins; transferring the SNF to the SNF Cold Vacuum Drying (CVD) Facility; storing and treating the sludge to meet the waste acceptance of the receiving facility; transferring the sludge to the receiving facility; pre-treating and transferring the water to the Effluent Treatment Facility (ETF); transferring the debris to appropriate facilities; treatment or disposal; and deactivating the basins. 


\begin{tabular}{|c|c|r|}
\hline & DOCUMENT: & HNF-4747 \\
REVISION: & 0 \\
DATE: & $06 / 30 / 99$ \\
PAGE: & 3 \\
\hline
\end{tabular}

FIGURE 1-1

Hälivid Sile Luention lial?

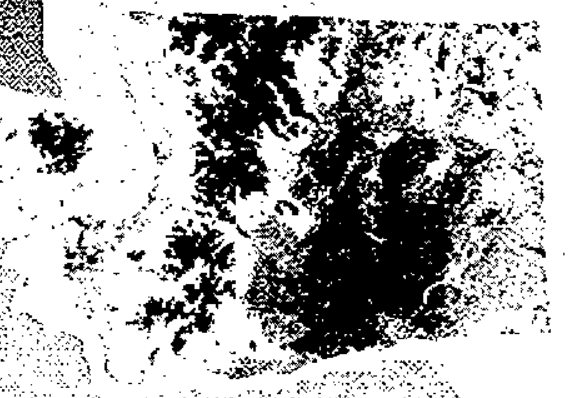

Washington State

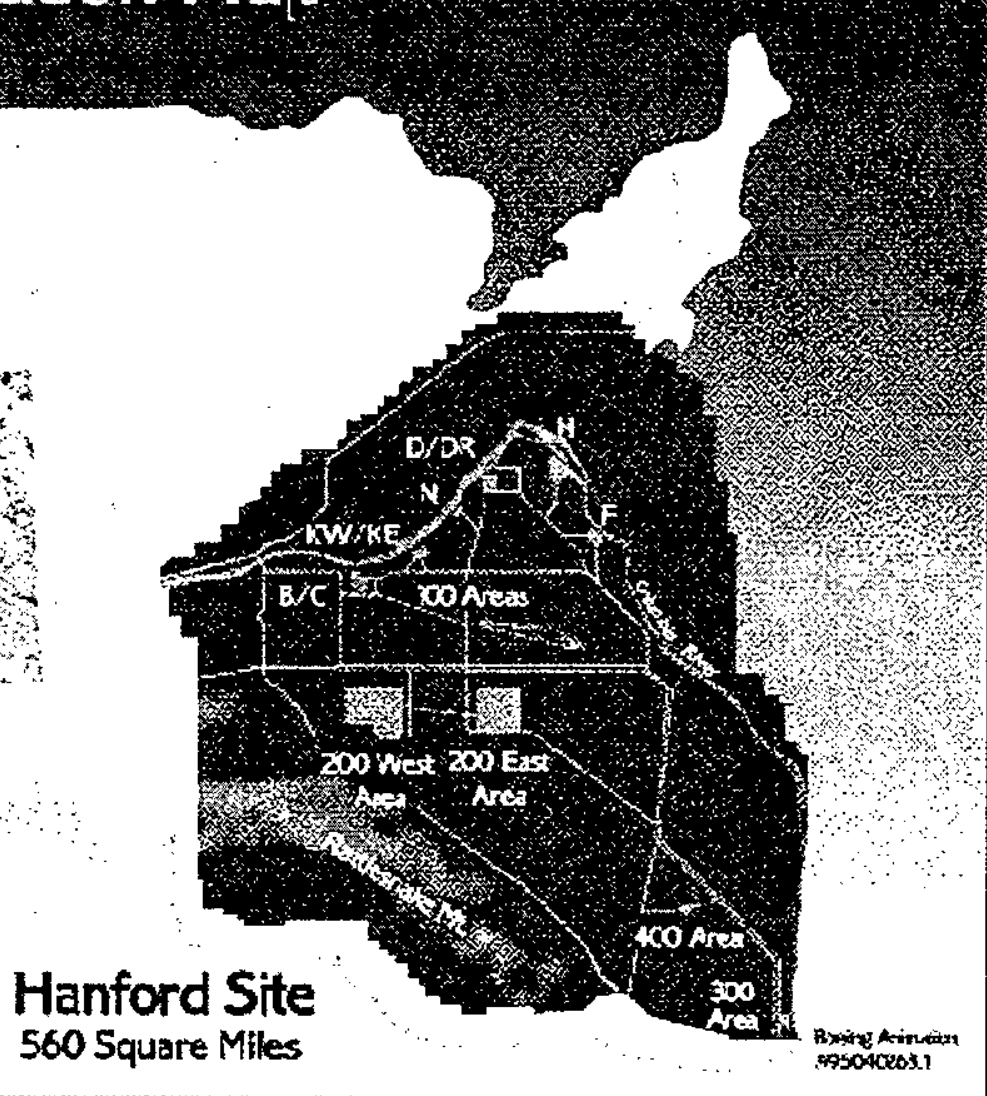




\begin{tabular}{|c|c|r|}
\hline & DOCUMENT: & HNF-4747 \\
REVISION: & 0 \\
DATE: & $06 / 30 / 99$ \\
PAGE: & 4 \\
\hline
\end{tabular}

\section{FIGURE 1-2; HANFORD MAP}

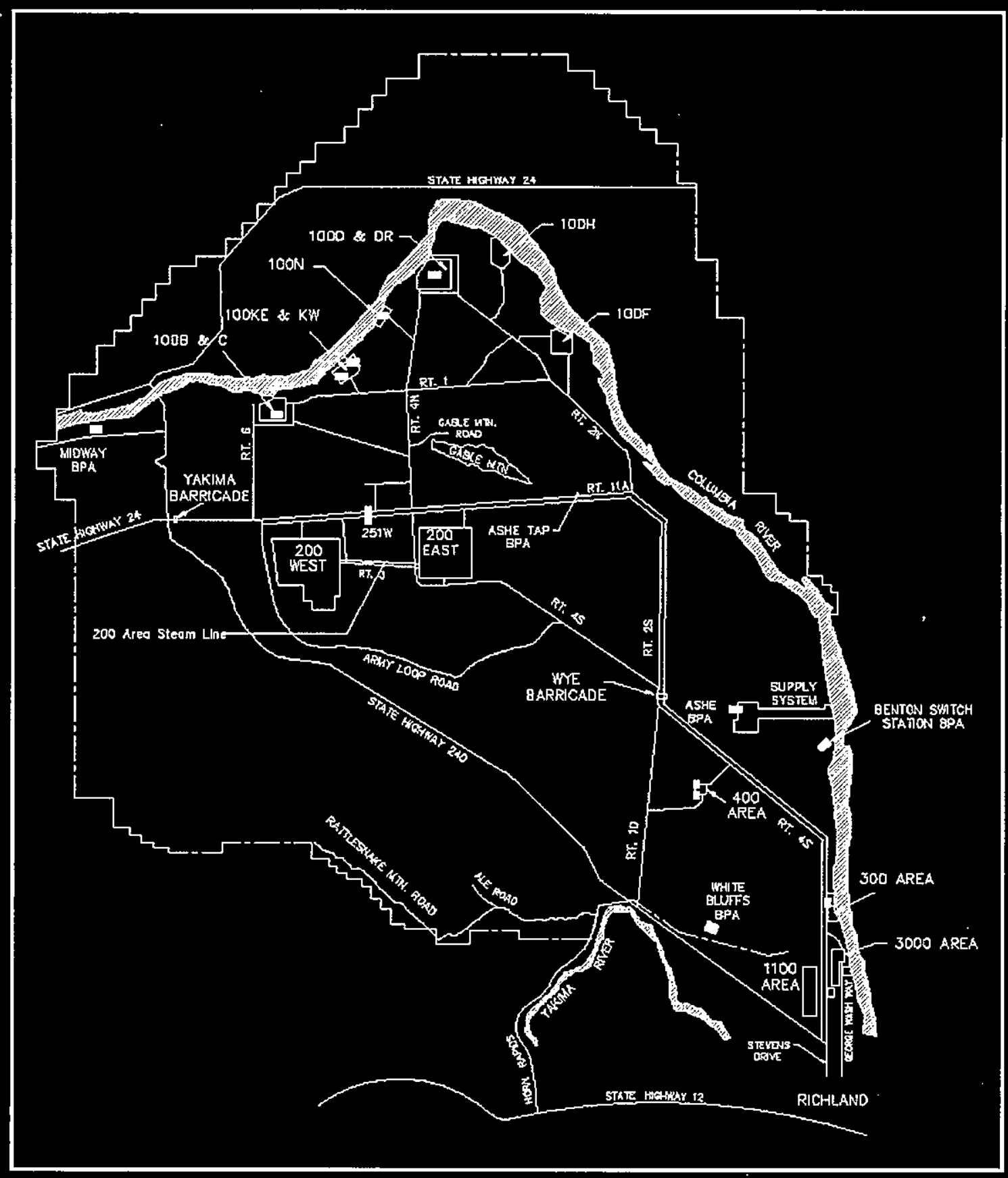




\begin{tabular}{|c|c|c|}
\hline & KOCUMENT: & HNF-4747 \\
\hline & HEVISION: & 0 \\
DATE: & $06 / 30 / 99$ \\
\hline
\end{tabular}

\subsection{DESCRIPTION OF WORK}

Design of several of the processes within the scope of the K Basins Interim Remedial Action have not yet been finalized. As a consequence, work element detail associated with these portions of the work scope are only addressed generically herein. The following subsections provide an overview of the K Basins Interim Remedial Action scope of work to be conducted under CERCLA.

\subsection{SNF Management}

Fuel elements are contained in outer metal jackets (cladding), some of which have degraded to the point that corroded fuel and cladding material have escaped from the canisters and mixed with the sludge on the floor of the basins. Fuel elements will be removed from their canisters, and loaded into "baskets". Loaded baskets will then be positioned over a specially fabricated container (Mult-Canister Overpack, [MCO]), and subsequently lowered into the MCO shipping cask. The entire operation will be conducted underwater to minimize radiation exposures to workers. The MCO shipping cask will then be raised out of the water, decontaminated, loaded onto a truck, and transported to the CVD Facility.

The primary hazards associated with SNF retrieval include direct radiation exposure, potential personnel contamination, potential inhalation of airborne concentrations of radioactive materials, and potential drowning via falling into a basin or pit. The latter potential (drowning) also includes severe personnel contamination, even if drowning does not occur. Lessor hazards may include falls, being struck by moving or stationary objects, tripping, cuts and abrasions, exposures to hazardous substances, and exposures to hazardous stored energy systems/devices.

\subsection{Sludge Management}

The total volume of sludge in the $\mathrm{K}$ East and $\mathrm{K}$ West Basins and pits is approximately 50 cubic meters (1,800 cubic feet), or 13,000 gallons (DOE98A). It is planned that the sludge will be moved from the basin and pit floors to a staging area. Thereafter, the sludge will be removed from the staging area to an as yet to be determined storage and treatment system. The treatment system will be designed to condition the sludge in such a manner so as to render it acceptable by the selected receiving facility. Treatment may consist of chemical, thermal or physical methods. 


\begin{tabular}{|c|c|r|}
\hline & DOCUMENT: & HNF-4747 \\
REVISION: & 0 \\
DATE: & $06 / 30 / 99$ \\
PAGE: & 6
\end{tabular}

The sludge management process is important to safety, as it will be unique to the $\mathrm{K}$ Basins sludge. By nature of its uniqueness, the selected process may have equally unique associated safety hazards, hence warranting a careful and detailed hazards analysis effort prior to initiation of work.

The primary hazards associated with sludge management include direct radiation exposure, potential personnel contamination, potential inhalation of airborne concentrations of radioactive materials, and potential drowning via falling into a basin or pit. The latter potential (drowning) also includes severe personnel contamination, even if drowning does not occur. Lessor hazards may include falls, being struck by moving or stationary objects, tripping, cuts and abrasions, exposures to hazardous substances, and exposures to hazardous stored energy systems/devices.

\subsection{Water Management}

The K Basins collectively contain approximately $9,800,000$ liters $(2,600,000$ gallons) of water contaminated with radioactive materials. This volume and any excess water inventory caused by decontamination activities using decontaminated water, return of water from the CVD Facility, etc., will be pretreated at the basins, transferred to the ETF in the 200 East Area for final treatment, and subsequently disposed of in accordance with State permit requirements.

Pretreatment at the basins will be accomplished by use of the existing water treatment systems currently serving the basins. These systems, however, will be upgraded and expanded to create an Integrated Water Treatment System (IWTS) for each basin. The IWTS will provide the necessary collection of contaminated basin water, treatment of the water, and recirculation of the treated water to the basins. Some of the water may be transferred directly to the ETF after the pretreatment step. Clean water will be added to the basins to maintain the levels necessary for continued operation. The IWTS will consist of filters to remove particulate matter, and ion exchange modules to remove the dissolved radioactive materials. Transport of treated water to the ETF will be accomplished through the use of tanker trucks.

Primary hazards associated with water management activities include direct radiation exposure, potential personnel contamination, potential inhalation of airborne radioactive materials, and potential drowning via falling into a basin or pit. The latter potential (drowning) also includes severe personnel contamination, even if drowning does not occur. Lessor hazards may include falls, being struck by moving or stationary objects, tripping, cuts and abrasions, exposures to hazardous substances, exposures to hazardous stored energy systems/devices, and transportation accidents.

\subsection{Debris Management}

Debris is defined as any solid waste with a size of 0.64 centimeters $(0.25$ inches) or greater, exclusive of SNF and sludge. This definition includes, but is not limited to, empty fuel canisters; old basin equipment and piping; hand tools; SNF fuel storage racks; equipment used 


\begin{tabular}{|c|c|r|}
\hline & DOCUMENT: & HNF-4747 \\
REVISION: & 0 \\
DATE: & $06 / 30 / 99$ \\
PAGE: & 7 BASINS INTERIM REMEDIAL ACTION \\
HEALTH AND SAFETY PLAN & & \\
\hline
\end{tabular}

to remove SNF, sludge, water and debris from the basin; spent ion exchange modules containing resins; old ion exchange columns packaged in burial boxes; components of the sludge treatment system when they are no longer required for service; and miscellaneous waste generated during deactivation of the basins. Debris will be removed from the basins throughout the duration of the Project including basin deactivation as well as basin clean out activities. Upon removal, debris will be classified for waste disposal purposes, decontaminated if necessary, packaged accordingly, and shipped to the appropriate storage or disposal facility.

Primary hazards associated with water management activities include direct radiation exposure, potential personnel contamination, potential inhalation of airborne concentrations of radioactive materials, and potential drowning via falling into a basin or pit. The latter potential (drowning) also includes severe personnel contamination, even if drowning does not occur. Lessor hazards may include falls, being struck by moving or stationary objects, tripping, cuts and abrasions, exposures to hazardous substances, exposures to hazardous stored energy systems/devices, and transportation accidents.

\subsection{Basin Deactivation}

Once the SNF, sludge, water, and debris have been removed from the $\mathrm{K}$ Basins, the basins will then be deactivated. Deactivation will involve those activities required to place the basins and necessary support facilities/equipment into a safe storage configuration. These activities may include removal, and subsequent shipment for storage and/or disposal, of equipment that is not integral to the basin structures; decontamination of basin surfaces; de-energizing those support systems no longer required for environmental compliance and personnel safety (e.g., electrical, heating, air conditioning, water supply, and monitoring systems/equipment); structural repairs as necessary; and the sealing of building penetrations to prevent entry by animals.

Primary hazards associated with basin deactivation activities include direct radiation exposure, potential personnel contamination, potential inhalation of airborne concentrations of radioactive materials, and potential drowning via falling into an open and drained basin or pit. Lessor hazards may include being struck by moving or stationary objects, tripping, cuts and abrasions, exposures to hazardous substances, exposures to hazardous stored energy systems/devices, and transportation accidents. It should be noted that it may be several years before deactivation is initiated. A detailed hazards analysis will be completed prior to the beginning of deactivation activities. 


\begin{tabular}{|c|c|rr|}
\hline & DOCUMENT: & HNF-4747 \\
\hline & REVSION: & 0 \\
DATE: & $06 / 30 / 99$ \\
\hline
\end{tabular}

\subsection{HEALTH AND SAFETY PROGRAM DESCRIPTION}

As indicated in the foregoing sections and Section 4.0, the K Basins Interim Remedial Action Project is comprised of a number of widely varying and complex subprojects and tasks. This variety in work scope has varying levels of hazard, hence application of safety and health controls. As a consequence of this variety, all details of this health and safety plan (HASP) may not be applicable to a specific subproject or task. To accommodate varying requirements between subprojects and tasks, this HASP permits the construction, review and approval of sub-tier HASPs which are specific to the scopes of work to be performed under the auspices of the specific subproject or task.

To assist in the development of sub-tier or task-/subproject-specific HASPs, the PHMC Automated Job Hazards Analysis (AJHA) will be used in accordance with HNF-PRO-079 (PHMC98A). The AJHA is a computer-based application to help planners identify the potential hazards associated with a job task, and to implement the proper controls based on the hazards identified. The program accomplishes this task by presenting the user with a panel of questions, which lead to controls based on the user's responses. Additional assistance is provided through a libraxy of previous AJHAs, a set of Hanford Site forms and permits which can be completed and stored electronically, and a method of indicating the involvement of Subject Matter Experts involvement electronically. At a minimum, the AJHA system, combined with the PHMC's Integrated Safety Management System, will accomplish the program elements/objectives summarized in Table 3-1.

Proper use of the AJHA in conjunction with this HASP, plus specifics associated with the task, will constitute acceptable sub-tier or task-/subproject-specific HASPs. Task specifics shall include a minimum of a detailed description of the work, and an organization specific to the work scope. The sub-tier HASP need not duplicate subject matter covered in this HASP, such as general medical surveillance requirements, basic training requirements, etc. Where applicable requirements are specified in this HASP, but not included in the sub-tier HASP, these additional requirements will be added to the sub-tier HASP. Examples might include special medical surveillance requirements not listed herein, such as blood lead bioassays and special training requirements for specific hazardous substances.

In accordance with 29 CFR 1910.12(6)(1)(v) (OSHA99A), this HASP shall be made available to PHMC employees and any contractor/subcontractor involved with hazardous waste operations. 


\begin{tabular}{|c|c|r|}
\hline & DOCUMENT: & HNF-4747 \\
REVISION: & 0 \\
DATE: & $06 / 30 / 99$ \\
PAGE: & 9 \\
\hline
\end{tabular}

TABLE 3-1: AJHA/ISMS PROGRAM ELEMENTS AND OBJECTIVES

PROGRAM ELEMENT

Identify the Hazards

Analyze Hazards and Implement Controls
Perform a pre-job safety walk down of the work area

Analyze each work element for identification of hazards

ACTION/ACTIVITY

Involve appropriate subject matter experts (SMEs), as may be required to determine specific controls Insure that personnel qualifications are specified Identify engineering and/or administrative controls which will mitigate the identified hazards, or the personal protective equipment (PPE) which must be used to guard against the identified hazard

Develop necessary methods and content for communicating the hazard's analysis to involved personnel

When work activities are expected, or have the potential, to exceed the substance-specific medical surveillance criteria, complete the AJHA Potential Exposure Hazard screen ${ }^{1}$. This action will activate the appropriate medical surveillance when transmitted to the Occupational Medical Provider.

Perform the Work Within Controls
Communicate identified hazards and specified controls to personnel performing the work

Ensure involved personnel are adequately qualified to perform the work

\footnotetext{
${ }^{1}$ Medical surveillance criteria are based on exposure information contained in the Employee Job Task Analysis( EJTA). The EJTA system is described in HNF-PRO-111 (PHMC97A). In the absence of EJTA substance specific information, the OSHA Permissible Exposure Limit (PEL) or the American Conference of Governmental Industrial Hygienists (ACGIH) Threshold Limit Value (TLV), whichever is lower, shall be used.
} 


\begin{tabular}{|c|c|c|}
\hline & DOCUMENT: & HNF-4747 \\
REVISION: & 0 \\
DATE: & $06 / 30 / 99$ \\
PAGE: & 10 \\
\hline
\end{tabular}

TABLE 3-1: AJHA/ISMS PROGRAM ELEMENTS AND OBJECTIVES (Cont.)

PROGRAM ELEMENT

Perform the Work Within Controls (Cont.)
Verify that workers executing the task are medically qualified

Ensure that all individuals involved in the work receive required training for the task

Monitor specified work practice(s) and control(s)

Feedback and Continuous

Improvement

Obtain worker feedback for the identification of unforeseen hazards, and work practices that can be made safer

Use lessons learned feedback to improve the effectiveness of work controls, and as an opportunity to clarify work instructions and procedures.

Perform self-assessments of the health and safety program implementation to determine effectiveness

Implement corrective actions as may be necessary to enhance safety 


\begin{tabular}{|c|c|r|}
\hline & DOCUMENT: & HNF-4747 \\
REVISION: & 0 \\
DATE: & $06 / 30 / 99$ \\
PAGE: & 11 \\
\hline
\end{tabular}

\subsection{PROJECT ORGANIZATION}

The organization of the SNF Project is shown in Figure 4-1. Figure 4-1 illustrates the chain of command for each major organizational function within the project, as well as specific lines of communication. Sub-organizations subordinate to that illustrated in Figure 4-1, are described in detail in the SNF Project Execution Plan (PEP) (FDH99A). The organizational charts and this section will be periodically reviewed and updated as necessary to ensure that contemporary roles, responsibilities and authorities that could significantly affect safety are accurately portrayed.

\subsection{Project Director}

The Project Director has overall responsibility and authority for directing all project work. This includes assuring that appropriate funding is in place to ensure that project activities can be conducted safely and efficiently. This responsibility and authority also includes the balancing of priorities to ensure that budget and/or schedule do not take precedence over safety and health. Authority for the execution of specific portions/tasks of the Interim Remedial Action is delegated to the appropriate management functions reporting to the Project Director. By definition herein, the Project Director is the functional equivalent of the "General Supervisor" defined in 29 CFR 1910.120(b)(2)(i)(A).

\subsection{Site Health and Safety Officer}

As indicated in Figure 4-1, the Site Health and Safety Officer (SHSO) function has been assigned to the Manager of Safety, Health and Emergency Planning. The Safety, Health and Emergency Planning Manager reports directly to and takes day-to-day direction from the Project Director; maintains independent authority to develop and ensure implementation of project-/subproject-HASPs, as well as the responsibility and authority to verify compliance with safety and health requirements. This vested authority is indicated in Figure $4-1$ by the dotted-line reporting relationship to the Fluor Daniel Hanford, Inc. (FDH) Office of Environment, Safety, Health and Quality Assurance. The Safety, Health and Emergency Planning organization is divided into three sub-functions, including Emergency Planning, Chemical Management, and Safety and Health. The SHSO duties and authorities may be delegated to the Safety and Health Manager for the purpose of implementing this HASP. SHSO responsibilities, however, are retained by the Safety, Health and Emergency Planning Manager to ensure compliance with the requirements of 29 CFR 1910.120(6)(2)(i)(B).

\subsection{Construction Projects}

Project construction execution responsibilities and authority are vested in the Construction Projects Manager function. The scope of the Interim Remedial Action Project Construction activities is limited to the $\mathrm{K}$ Basin subproject. The Construction Project Manager also has 


\begin{tabular}{|c|c|r|}
\hline & DOCUMENT: & HNF-4747 \\
REVISION: & 0 \\
DATE: & $06 / 30 / 99$ \\
PAGE: & 12 \\
\hline
\end{tabular}

responsibility for the Canister Storage Building, the Cold Vacuum Drying, and the Storage Subprojects. Each of these subprojects is further divided into major tasks/functions. Upon completion of construction facility/systems, operations are transferred to the Operations Manager.

\subsection{Operations}

The operational aspects of the Interim Remedial Action are the responsibility of the Operations Manager. The Operations Manager is responsible for all operations at the four major facilities plus general operations support, training and procedures, SAR implementation, integrated scheduling, maintenance, and work control.

\subsection{Project Controls}

The cost and schedule aspects of the Interim Remedial Action Project are the responsibility of the Project Controls Manager. The Project Controls Manager is responsible for five major functions, including Cost \& Scheduling Reporting, Project Execution/Planning, Life-cycle Estimating, Baseline Management, and the Risk and Opportunity Management function. Each of these major functions is further divided into sub-functions that are necessary for supporting the Project.

\subsection{Performance Improvement and Regulatory Services}

Regulatory support, corrective action management and self-assessment functions are the responsibility of the Manager of Performance Improvement and Regulatory Services. The Performance Improvement and Regulatory Services group is divided into four major functions, including Self Assessment, the Corrective Action Program, Environmental Protection, and Regulatory Interface/Technical Support. Each of these major functions is further divided into logical sub-functions that support the Project. The Performance Improvement and Regulatory Services' Self Assessment and Corrective Action Program sub-functions will perform Health and Safety Program assessments independent of the internal assessments performed be the SHSO function.

\subsection{Quality Assurance}

The Quality Assurance (QA) function is responsible for developing and maintaining the SNF Project QA Program, as well as establishing and interpreting QA criteria for Project organizations. The QA organization is divided into three sub-functions, including QA Surveillance, QA Programs/Projects, and QA Operations. Within the QA Organization, these sub-functions have responsibilities for: interpreting and approving QA program requirements; identifying quality problems, and initiating, recommending or providing solutions to identified problems, and the verification of the solutions; performing oversight activities on subcontractor scopes of work to verify implementation of QA requirements; overview of project management's implementation of the QA program and implementing procedures; review of project documentation; and the preparation and support of operational readiness review activities to ensure acceptable incorporation of $Q A$ requirements. 


\begin{tabular}{|c|c|r|}
\hline & DOCUMENT: & HNF-4747 \\
REVISION: & 0 \\
DATE: & $06 / 30 / 99$ \\
PAGE: & 13 \\
\hline
\end{tabular}

\subsection{Engineering}

The Engineering organization is responsible for establishing, implementing and maintaining the engineering technical baseline, authorization bases, and nuclear safety regulatory compliance.

The Engineering organization is divided into nine sub-functions, including Technical Operations, Nuclear Safety, Process Engineering, Systems Engineering, Plant Engineering Electrical/Chemical, Plant Engineering - Mechanical/Civil, Plant Engineering - Requirements, SNF Characterization Project, and Technical Integration. The Engineering organization's charter includes the responsibility for ensuring the technical adequacy of all SNF Project facilities systems, structures and components.

\subsection{Startup Integration}

Start-up Integration is responsible for administering the SNF Operational Readiness Review (ORR) process. An ORR is a disciplined, systematic, documented, performance-based examination of facilities, equipment, personnel, procedures, and management control systems to ensure that a facility will be started and operated within its approved safety envelope, as defined by the facility's authorization basis. A separate independent contractor and DOE ORR shall be conducted for the SNF Project. The ORR group develops the Plan of Action (which defines the scope of the ORR), develops the Management Self-Assessment (MSA) criteria appraisal forms, and reviews each completed MSA appraisal. The ORR group additionally tracks deficiencies identified in the MSA and administers the contractor/DOE ORRs.

\subsection{Radiological Control}

The Radiological Control organization provides radiation safety services to the SNF Project. The group ensures the radiological safety of workers, the public, and the environment. This encompasses the "as-low-as-reasonably-achievable" (ALARA) principles, contamination control, and safe radiological practices.

\subsection{Other Project Functions}

Other organizational functions supporting the project include Contracts, Integration Projects, and Technical Staff. 


\begin{tabular}{|c|c|r|}
\hline & DOCUMENT: & HNF-4747 \\
REVISION: & 0 \\
DATE: & $06 / 30 / 99$ \\
PAGE: & K BASINS INTERIM REMEDIAL ACTION & 14 \\
\hline
\end{tabular}

FIGURE 4-1

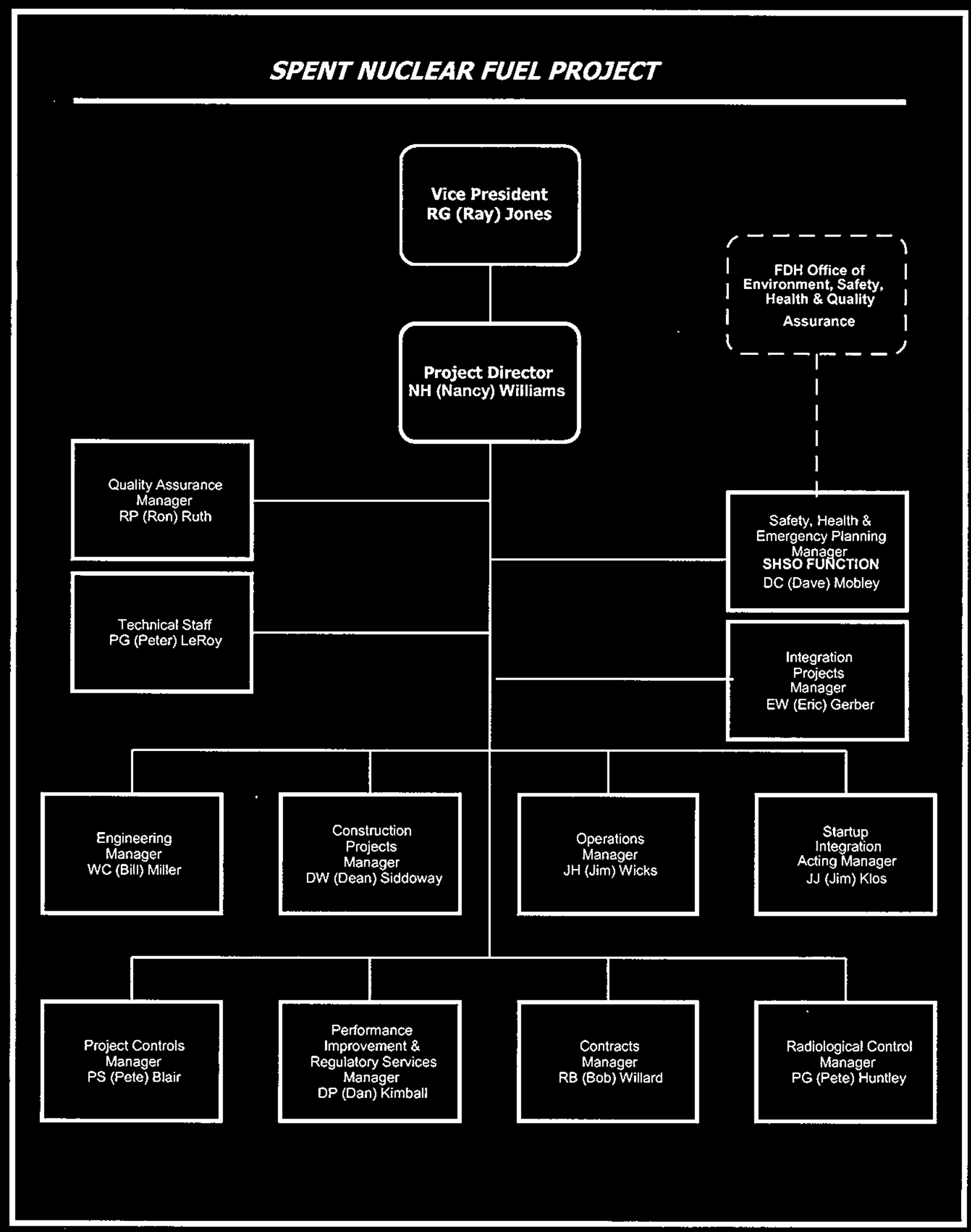




\begin{tabular}{|c|c|r|}
\hline & DOCUMENT: & HNF-4747 \\
REVISION: & 0 \\
DATE: & $06 / 30 / 99$ \\
PAGE: & 15 \\
\hline
\end{tabular}

\subsection{HAZARD IDENTIFICATION}

A walk-down of the 105-K West Basin was conducted in March of 1999 to qualitatively assess the applicability and nature of various potential industrial hazards intrinsic to the facility. The objective of the facility walk-down was to provide relevant data and descriptions of potential facility hazards, as well as the accompanying engineered and administrative mitigators, which would be used as a basis for the site-specific Health and Safety Plan.

The observations made during the walk-down were divided into four broad categories: Kinetic Energy Hazards, Chemical Hazards, Electrical Hazards, and Other Industrial Hazards. Four tables were constructed for each of these categories to be used as checklists during the actual walkdown of the facility. The actual walk-down included meetings and interviews with facility personnel, observations of posting and labeling, and an escorted tour of the facility and a closeout.

The Kinetic Energy Hazards table was subdivided into 13 individual hazard types, each of which was individually assessed as to its applicability to the facility, and, if applicable, the nature and relative severity of the potential hazard. For each applicable potential hazard, any apparent mitigative features or administrative controls were noted in the Description/Observation section of the table. This approach was followed for all four tables (one for each hazard category).

For Kinetic Energy Hazards, 11 out of a potential 13 hazard types were considered potentially applicable. For Electrical Hazards, 9 out of a potential 11 hazard types were considered potentially applicable. Two potential hazard types, both pertaining to electrical grounding, could not be effectively assessed. For Chemical Hazards, 10 out of a potential 14 hazard types were considered potentially applicable. For Other Industrial Hazards, 13 out of a potential 18 hazard types were considered potentially applicable. Other Industrial Hazards included: Biological Hazards, Confined Space Hazards, Fire/Flammables Control, Temperature Extremes, and Noise and Fugitive Dust Generation and Control.

Hazards identified during this evaluation are summarized in the following subparagraphs and tables. This summary is not intended to be inclusive of all hazards which may exist at the time work is executed, or that may be presented as artifacts of the work itself. Instead, the protocols identified herein shall be used to identify and mitigate subproject-specific hazards. 


\begin{tabular}{|c|c|r|}
\hline & DOCUMENT: & HNF-4747 \\
REVISION: & 0 \\
DATE: & $06 / 30 / 99$ \\
PAGE: & 16 \\
\hline
\end{tabular}

\subsection{HAZARD MITIGATION AND CONTROL}

Table $6-1$ contains a summary of the hazards identified for the SNF Project. Hazards identified in this table are discussed in more detail in the paragraphs following the table.

TABLE 6-1: HAZARDS IDENTIFICATION

\begin{tabular}{|c|c|c|c|}
\hline \multicolumn{4}{|c|}{ HAZARDS IDENTIFICATION SUMMARY } \\
\hline & HAZARD & NOTE(s) & $\begin{array}{l}\text { PERMISSIBLE EXPOSURE LIMITS }{ }^{2} \\
\text { OR MITIGATIVE REQUIREMENTS }\end{array}$ \\
\hline$x$ & Airborne Pathogens & $\begin{array}{l}\text { Hantavirus (Deer Mouse) } \\
\text { Histoplasma capsulatum, } \\
\text { results in Histoplasmosis } \\
\text { (bird guano) }\end{array}$ & $\begin{array}{l}\text { No known standards } \\
\text { No known standards }\end{array}$ \\
\hline$X$ & $\begin{array}{l}\text { Asbestos and } \\
\text { Asbestos Containing } \\
\text { Materials (ACM) }\end{array}$ & Pipe lagging \& Transite & $\begin{array}{l}\text { TWA: } 0.1 \text { fiber } / \mathrm{cm}^{3} \\
\text { Excursion Limit: } 1.0 \text { fiber } / \mathrm{cm}^{3} \\
\text { Reference: } 29 \text { CFR } 1910.1001\end{array}$ \\
\hline$x$ & $\begin{array}{l}\text { Biological - } \\
\text { Poisonous/toxic } \\
\text { insects } \\
\text { And reptiles }\end{array}$ & $\begin{array}{l}\text { Indigenous to the local area - } \\
\text { Hobo spider, black widow } \\
\text { spider, wood tics, wasps, } \\
\text { rattlesnakes, etc. }\end{array}$ & No known standards \\
\hline$x$ & $\begin{array}{l}\text { Bloodborne } \\
\text { pathogens }\end{array}$ & $\begin{array}{l}\text { Hepatitis B virus } \\
\text { Human immunodeficiency } \\
\text { virus }\end{array}$ & 29 CFR 1910.1030 \\
\hline$X$ & Confined spaces & Basins and pits & $\begin{array}{l}29 \text { CFR } 1910.46 \\
29 \text { CFR } 1910.46 \text { Appendices A - D \& F }\end{array}$ \\
\hline$x$ & $\begin{array}{l}\text { Cuts, abrasions, and } \\
\text { punctures }\end{array}$ & $\begin{array}{l}\text { Sharp edges/tools } \\
\text { Protruding structural } \\
\text { elements }\end{array}$ & $\begin{array}{l}29 \text { CFR } 1910.136 \\
29 \text { CFR } 1910.138 \\
29 \text { CFR } 1910 \text { Subpart I, Appendix B }\end{array}$ \\
\hline$x$ & Drowning & Basins/pits & 29 CFR 1926.106 \\
\hline$x$ & Electrical shock & $\begin{array}{l}\text { General - hand tools, } \\
\text { extension cords, temporary } \\
\text { wiring, etc. }\end{array}$ & $\begin{array}{l}29 \text { CFR } 1910.301-1910.308 \\
29 \text { CFR } 1910.331-1910.335 \\
29 \text { CFR 1910.269 Appendix C }\end{array}$ \\
\hline
\end{tabular}

2 TWA $=$ Time Weighted Average: Concentration to be averaged over an 8-hour period. Excursion Limit: Concentration to be averaged over a sampling period of 30 minutes 


\begin{tabular}{|c|c|c|}
\hline & DOCUMENT: & HNF-4747 \\
REVISTON: & 0 \\
DATE: & $06 / 30 / 99$ \\
PAGE: & 17 \\
\hline
\end{tabular}

TABLE 6-1: HAZARDS IDENTIFICATION (Cont.)

\begin{tabular}{|c|c|c|c|}
\hline \multicolumn{4}{|c|}{ HAZARDS IDENTIFICATION SUMMARY } \\
\hline & HAZARD & NOTE(s) & $\begin{array}{l}\text { PERMISSIBLE EXPOSURE LIMITS } \\
\text { OR MITIGATIVE REQUIREMENTS }\end{array}$ \\
\hline$x$ & $\begin{array}{l}\text { Falling/falling } \\
\text { objects }\end{array}$ & $\begin{array}{l}\text { Work surfaces elevated } \\
>4 \text { feet }\end{array}$ & $\begin{array}{l}29 \text { CFR } 1910.23 \\
\text { Various others - see: } \\
29 \text { CFR } 1910 \text { Subpart F } \\
29 \text { CFR } 1910 \text { Subpart I } \\
29 \text { CFR } 1910 \text { Subpart N }\end{array}$ \\
\hline$x$ & Fire/explosion & Flammable liquids/gases & 29 CFR 1910 - Subpart L \\
\hline$x$ & Hazardous chemicals & $\begin{array}{l}\text { Carcinogenic } \\
\text { Toxic }\end{array}$ & $\begin{array}{l}\text { See Sub-Section } 6.16 \\
29 \text { CFR } 1910 \text { Subpart Z }\end{array}$ \\
\hline$x$ & Noise & Equipment operations & $\begin{array}{l}>85 \mathrm{~dB} \text { of the A scale, slow response for } \\
\text { a period of } 8 \text {-hours. Higher levels may } \\
\text { be permitted for shorter durations - See } \\
\text { Table } 6-11.29 \text { CFR } 1910.95\end{array}$ \\
\hline$x$ & Radiological & $\begin{array}{l}\text { Direct radiation } \\
\text { Surface contamination } \\
\text { Airborne contamination }\end{array}$ & $\begin{array}{l}\text { See sub-Section } 6.15 \\
10 \text { CFR } 835 \text { - all } \\
\text { DOE/RL-96-109, Rev. } 0\end{array}$ \\
\hline$x$ & $\begin{array}{l}\text { Stored hazardous } \\
\text { energy - non- } \\
\text { electrical }\end{array}$ & $\begin{array}{l}\text { Chemical } \\
\text { Hydraulic } \\
\text { Mechanical } \\
\text { Pneumatic } \\
\text { Thermal }\end{array}$ & 29 CFR 1910.147 \\
\hline$x$ & $\begin{array}{l}\text { Temperature } \\
\text { extremes - Heat }\end{array}$ & $\begin{array}{l}\text { Use of PPE } \\
\text { Outside work }\end{array}$ & $\begin{array}{l}\text { No OSHA standard } \\
\text { See OSHA Technical Manual } \\
\text { TED 1-0.15A for guidance }\end{array}$ \\
\hline$x$ & $\begin{array}{l}\text { Temperature } \\
\text { extremes - Cold }\end{array}$ & Outside work & $\begin{array}{l}\text { No OSHA Standard } \\
\text { See OSHA Publication No. } 3156 \text { for } \\
\text { information/training }\end{array}$ \\
\hline$x$ & Tripping/Slipping & $\begin{array}{l}\text { Cluttered or wet work } \\
\text { surfaces }\end{array}$ & 29 CFR 1910.22 \\
\hline
\end{tabular}

3 TWA $=$ Time Weighted Average: Concentration to be averaged over an 8-hour period. Excursion Limit: Concentration to be averaged over a sampling period of 30 minutes 


\begin{tabular}{|c|c|r|}
\hline & DOCUMENT: & HNF-4747 \\
REVISION: & 0 \\
DATE: & $06 / 30 / 99$ \\
PAGE: & 18 \\
\hline
\end{tabular}

TABLE 6-1: HAZARDS IDENTIFICATION (Cont.)

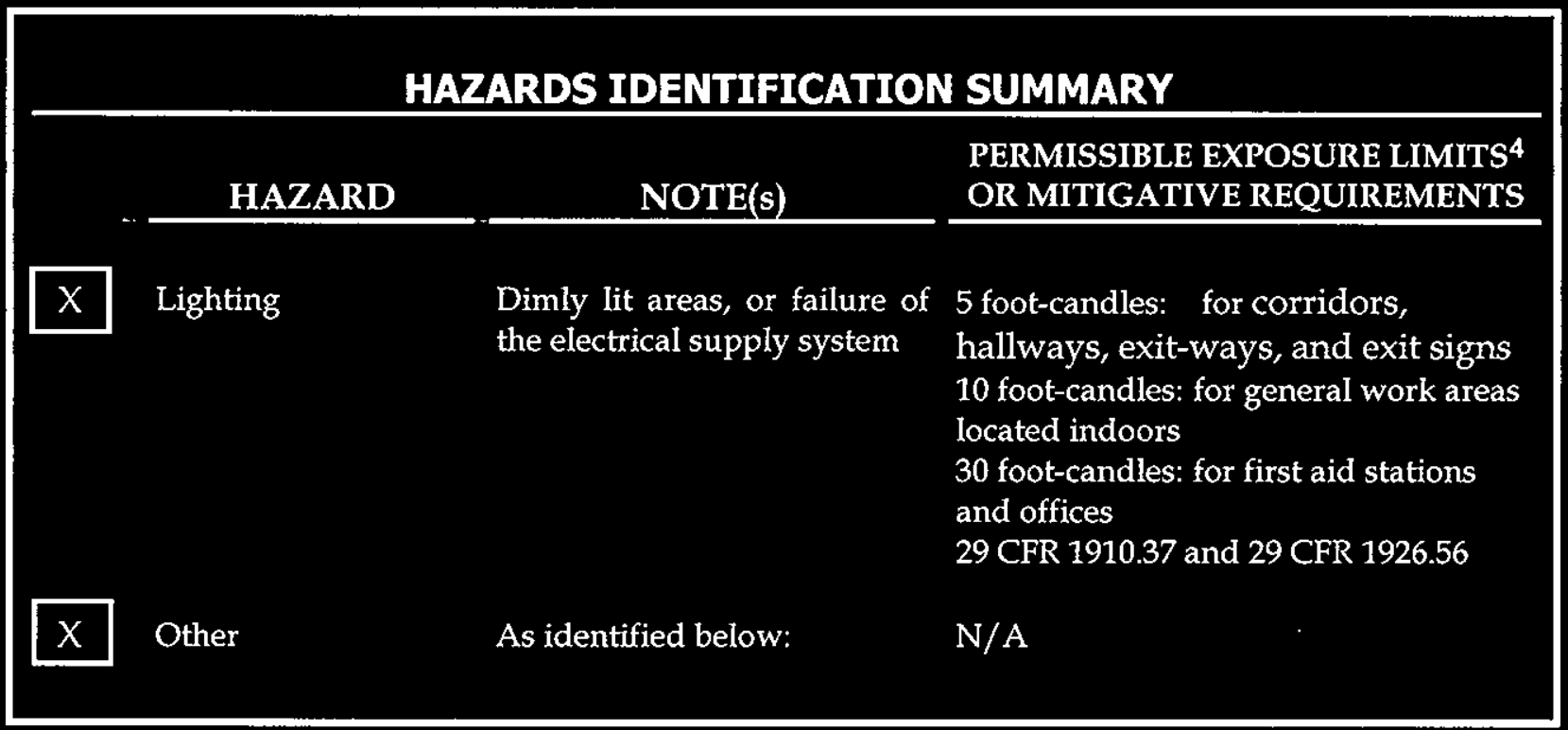

\subsection{Airborne Pathogens}

The potential for exposure to either the Hantavirus or the Histoplasma capsulatum fungus is considered to be low to very low, but not nonexistent. If removal/decontamination of rodent and/or bird/bat droppings is to be undertaken, affected personnel will be afforded appropriate Personnel Protective Equipment (PPE), will be trained and will be provided with the appropriate medical surveillance. If rodent droppings are observed, traps and poisons shall be used to rid the affected areas.

\subsection{Asbestos}

Air sampling for asbestos will be periodically performed to ensure absence of a hazard to workers. Abatement will be undertaken when measured concentrations exceed or threaten to exceed the applicable limits. Abatement actions will only be taken by individuals who have been properly trained, and are in the appropriate medical surveillance program. All work in the vicinity of asbestos containing materials, or presumed asbestos containing materials, shall comply with the terms and conditions of HNF-PRO-408 (PHMC97A).

4 TWA = Time Weighted Average: Concentration to be averaged over an 8-hour period. Excursion Limit: Concentration to be averaged over a sampling period of 30 minutes 


\begin{tabular}{|c|c|r|}
\hline & DOCUMENT: & HNF-4747 \\
REVISTON: & 0 \\
DATE: & $06 / 30 / 99$ \\
PAGE: & 19 \\
\hline
\end{tabular}

\subsection{Other Poisonous/Nenomous Fauna}

Work spaces will be periodically surveyed for infestations of spiders, wasps, bees, and snakes. Poisons will be used to kill insects. Egg sacs, webs, combs, and other such residence structures will be destroyed as they are discovered. Employee training will include recognition, avoidance, and reporting requirements.

\subsection{Bloodborne Pathogens}

The potential for exposure to bloodborne pathogens is considered to be low. Standard precautionary measures such as cleaning and sanitizing of respirators, and the use of barriers and PPE in the administration of first aid will be exercised. Only properly trained employees will administer first aid. Only respirators cleaned and sanitized according to manufacturers' recommendations will be used. Other requirements, such as provisions for "good samaritan" acts, shall be in accordance with the terms and conditions of HNF-PRO-584 (PHMC97B).

\subsection{Confined Spaces}

All entries into confined spaces will require that a Confined Space Hazard Identification be completed, and compliance with applicable conditions of HNF-PRO-110 (PHMC97C).

\subsection{Cuts/Abrasions and Punctures}

Preventive measures will be taken to eliminate or minimize worker exposure to sharp edges and/or points. PPE shall be used where exposure to sharp edges and/or points can not be eliminated. Personnel training shall be conducted in the proper use of selected or designated PPE.

\subsection{Drowning}

Engineered barriers shall be utilized to preclude personnel access to the basins. Whenever access barriers must be removed for special purpose work, fall protection systems will be utilized to mitigate the drowning potential hazard.

\subsection{Electrical Shock}

All electrical equipment shall be Underwriters' Laboratories (UL) listed or equivalent. Ground fault circuit interrupters (GFCI) shall be used on all receptacles that are not part of the permanent structure wiring, and in damp or wet working areas. Compliance with specific additional requirements and guidance of HNF-PRO-088 (PHMC98B) will be required.

\subsection{Falling/Falling Objects}

Working and walking surfaces which have openings, from which there is a drop of more than four feet shall be guarded by standard slats, standard grill work (as specified in paragraph

(e)(11) of 29 CFR 1910.23), or standard railing. Where it is impractical to provide such engineered barriers, alternative fall protection will be provided. Such alternative protection 


\begin{tabular}{|c|c|rr|}
\hline & DOCUMENT: & HNF-4747 \\
\hline & KEVISION: & 0 \\
DATE: & $06 / 30 / 99$ \\
PAGE: & 20 \\
\hline
\end{tabular}

shall conform to the standards specified in Occupational Safety and Health Act (OSHA) Directive Number 75-40. Whenever persons can pass beneath the open sides, there is moving machinery beneath the open sides, or there is equipment with which falling materials could create a hazard, installed guards shall also include toe boards. With the exception of the aforementioned, the Project will comply with all provisions of HNF-PRO-092 (PHMC97D).

\subsection{Fire/Explosion}

Project activities and procedures will focus on preventing fires and explosions through adherence to the following precautions and procedures:

\subsubsection{Combustibles}

The accumulation and/or use of combustible materials will be controlled in accordance with the provisions of HNF-PRO-359 (PHMC97E), and HNF-PRO-358 (PHMC97F). Accumulations of combustible materials in areas of high radioactive materials inventories shall not be permitted.

\subsubsection{Welding Cutting and Grinding}

Both high-hazard hot work (i.e., electric arc welding, oxy-fuel gas welding/cutting, heavy grinding, etc.) and low-hazard hot work (i.e., brazing, tig-welding, light grinding, etc.) shall be conducted in accordance with the provisions of HNF-PRO-356 (PHMC98C).

\subsubsection{Fire Watch}

Fire watches shall be established and maintained in accordance with the provisions of HNF-PRO-356 (PHMC98C).

\subsubsection{Periodic Inspections}

When non-routine Project activities dictate the generation or use of combustible materials, a qualified fire protection engineer will specify locations for accumulation of waste combustible materials. In addition, the fire protection engineer will conduct random inspections of work areas and facilities for transient combustibles.

\subsubsection{Portable Heaters}

The use of portable heaters in the close proximity of combustible materials shall be prohibited. Use of portable heaters shall be in accordance with the provisions of HNF-PRO-355 (PHMC97G). 


\begin{tabular}{|c|c|r|}
\hline & ROCUMENT: & HNF-4747 \\
REVISION: & 0 \\
DATE: & $06 / 30 / 99$ \\
PAGE: & 21 \\
\hline
\end{tabular}

\subsubsection{Monitoring}

Monitoring for combustible gases shall be required immediately before any hot work commences, provided that a combustion potential exists.

\subsection{Noise}

Workers shall be provided approved hearing protection devices any time that continuous, intermittent, impulsive, and/or impact noise levels attain or exceed a Time Weighted Average of 85 decibels on the A-Weighting scale (dBA), as measured with a sound meter at slow response. Additional permissible levels for exposure durations less than eight hours are provided in Table 6-11. Hearing protection shall also be provided to employees who have experienced a standard threshold shift. All other OSHA required aspects of a hearing conservation program; including monitoring, employee training, and medical surveillance, shall be conducted in accordance with the provisions of HNF-PRO-115 (PHMC97H).

TABLE 6-11

\begin{tabular}{|cc|}
\hline \multicolumn{2}{|c|}{ PERMISSIBLE NOISE EXPOSURES $1^{-1}$} \\
\hline Duration per day, in hours & Sound level - dBA slow response \\
\hline 24 & 80 \\
16 & 82 \\
8 & 85 \\
4 & 88 \\
2 & 91 \\
1 & 94 \\
$1 / 2$ & 97 \\
$1 / 4$ & 100 \\
& \\
Note 1: Additional limits for exposure periods less than 15 minutes (1/4 hour) are provided \\
in HNF-PRO-115.
\end{tabular}

\subsection{Stored Hazardous Energy (Lockout/Tagout)}

Workers shall be protected against unexpected releases of stored energy and/or hazardous materials through the use of locking or tagging energy isolating devices, or use of devices that prevent the release of hazardous materials. A Hazardous Energy Control Program shall be prepared for the Project in accordance with the provisions of HNF-PRO-081 (PHMC97I). 


\begin{tabular}{|c|c|r|}
\hline & DOCUMENT: & HNF-4747 \\
REVISION: & 0 \\
DATE: & $06 / 30 / 99$ \\
PAGE: & 22 \\
\hline
\end{tabular}

\subsection{Temperature Extremes}

Workers shall be protected against exposures to temperature extremes. To the maximum extent practicable, protection will be engineered into work place environments. Where engineered controls are not practicable, or where other work requirements reduce the effectiveness of engineered controls (e.g., the use of PPE), measures shall be taken to mitigate the effects of heat and cold stress, and to prevent the occurrence of heat exhaustion and hypothermia. The occurrence of heat stress is considered to be of a higher probability (medium to high) than the occurrence of hypothermia (low). The project shall conduct operations in accordance with the provisions of HNF-PRO-121 (PHMC97J). Workers involved in cold weather operations conducted outside of protective structures shall be afforded appropriate protective clothing; be briefed in the recognition of the symptoms of frost nip, frost bite, and hypothermia; and be provided the latitude to take advantage of rest periods inside heated protective structures. Hot and cold stress controls will be included in the AJHA.

\subsection{Tripping/Slipping}

Work areas shall be maintained in an orderly condition and free of tripping hazards. To the extent practicable, all working surfaces shall be kept clean and dry. Liquid spills shall be cleaned as soon after occurrence as may be practicable. Means of access and egress shall be well identified and kept clear of obstacles. The Project shall adhere to such other controls and practices as specified in HNF-PRO-091 (PHMC97K).

\subsection{Radiation}

The PHMC has a robust and mature radiation protection program. This program is described in the Hanford Site Radiological Control Manual (HSRCM) (DOE96A). The HSRCM fully implements Title 10 Code of Federal Regulations Part 835, Occupational Radiation Protection (DOE93A), as currently amended. The planning of work involving radiation and radioactive materials hazards is further described in HNF-PRO-1623, Radiological Work Planning Process (PHMC98D). Implementation of radiological work and radiation protection activities is detailed in more than 70 procedures. These procedures address all aspects of the Hanford Site Radiation Protection Program, including roles and responsibilities, qualifications, training, implementation of the As Low As Reasonably Achievable (ALARA) philosophy, external and internal dosimetry, monitoring and surveillance, work control mechanisms (e.g., Radiation Work Permits, and access and entry requirements), self-assessments, and use of specific radiation monitoring devices and meters. Task-/subproject-specific radiological hazard controls are identified through the use of the AJHA described in Section 3.0.

The PHMC Radiation Protection Program satisfies all of the requirements of 29 CFR 1910.120 for a health and safety program for radiological hazards. As a consequence, this HASP will not impose any new or different requirements. The program will be implemented such that personnel radiation exposures are maintained ALARA. 


\begin{tabular}{|c|c|r|}
\hline & DOCUMENT: & HNF-4747 \\
REVISION: & 0 \\
DATE: & $06 / 30 / 99$ \\
PAGE: & 23 \\
\hline
\end{tabular}

\subsection{Hazardous Substances}

The 100K Area has in excess of 500 Material Safety Data Sheets (MSDS) for a wide variety of materials, compounds, and substances. Collectively, these materials can be classed as laboratory/field test kit reagents, lubricants/oils, coatings and coverings, sealants, adhesives, acids, bases, fuels, cleaners, salts, dispersants, insecticides, abrasives, solvents, compressed gases, and various flammables (e.g., charcoal starter, lighter fluid). A large fraction of these materials present a low level of hazard, or are in very dilute and/or small quantities. In addition, an undetermined number of substances currently contained in the MSDS listing will likely never be used on the Project. Also, new and as yet unidentified substances and materials will likely be required for the Project. As a result, specific substances, their associated hazards, and mitigative measures will not be listed herein. Instead, the PHMC Chemical Management Program (CMP), as described in HNF-PRO-2258 (PHMC98E), in conjunction with implementation of the AJHA, will be relied upon to protect the worker, general public, and the environment. The CMP provides direction for the acquisition, storage, transportation, use, final disposition, record keeping, and management review of program performance for chemicals at the Hanford Site. Sub-elements of the CMP are provided in Table 6-16.

TABLE 6-16: CHEMICAL MANAGEMENT PROGRAM ATTRIBUTES

PROGRAM ELEMENT

\section{REQUIRED ACITON}

Acquisition

Transportation

Determine if excess chemicals from onsite contractors can be used in lieu of new chemical purchases

Justify the need for the chemical

Specify amount required

Explore a non-hazardous or less hazardous alternative

Specify plans for final disposition

Determine suitability of storage facilities

Specify the chemical's stability/shelf life

Obtain required safety documentation (e.g., MSDS)

Input chemical information into the Chemical Management tracking system

Ensure compliance with all applicable regulatory and procedural requirements

Ensure that chemical records are updated as appropriate 


\begin{tabular}{|c|c|r|}
\hline & DOCUMENT: & HNF-4747 \\
REVISION: & 0 \\
DATE: & $06 / 30 / 99$ \\
PAGE: & 24 \\
\hline
\end{tabular}

TABLE 6-16: CHEMICAL MANAGEMENT PROGRAM ATTRIBUTES (Cont.)

PROGRAM ELEMENT

REQUIRED ACITON

Use

Perform appropriate hazard analysis: generically (e.g., for a store stock item), or as part of a facility-/task-specific process or operation

Implement use of appropriate controls in the following hierarchy: engineered controls, administrative controls, and the use of PPE

Implement tracking, if new chemicals are created and not immediately used

Ensure that use is covered by either procedure or MSDS

Final Disposition

Ensure compliance with all applicable laws and regulations

Make available for use by others, or for recycle, before relegating to disposal

Transfer relevant documentation and information to the appropriate infrastructure functions

Records

Create and maintain records to show the following minimum information:

Location

Amount

Uses

Hazards

Custodian(s)

Management Review

Periodic assessment of program performance, including:

Establishing performance objectives

Identification of nonconformance(s)

Implementation/conformation of corrective actions 


\begin{tabular}{|c|c|r|}
\hline & DOCUMENT: & HNF-4747 \\
\hline & REVISION: & 0 \\
DATE: & $06 / 30 / 99$ \\
PAGE: & 25 \\
\hline
\end{tabular}

While the CMP provides for general provisions for procurement, transportation, storage and use of hazard chemicals, materials and substances, it does not provide the specificity required by 29 CFR 1910.120. That specificity is satisfied, however, through use of the AJHA, as summarized in Section 3.0. As a consequence, hazard mitigation and control for specific hazardous chemicals will be detailed in the task-/subproject-specific HASP.

\subsection{Illumination}

Work areas shall be provided with adequate illumination at the following minimum levels:

Indoors: warehouses, corridors, hallways, exit-ways,

and at the surface of illuminated exit signs .5 foot-candles

General plant and shop areas (e.g., mechanical and electrical equipment rooms, carpenter shops, rigging lofts, active store rooms, lunch rooms, and toilets and workrooms. .10 foot-candles

First-aid stations and offices. .30 foot-candles

The SHSO shall ensure that periodic measurements are made to verify the presence of adequate lighting. 


\begin{tabular}{|c|c|r|}
\hline & DOCUMENT: & HNF-4747 \\
REVISION: & 0 \\
DATE: & $06 / 30 / 99$ \\
PAGE: & 26 \\
\hline
\end{tabular}

\subsection{TRAINING}

\subsection{Discussion}

The Hanford Site has an established training system covering most, if not all, operational and safety aspects of site operations, including the training required by this section. The following subsections specify the minimum regulatory training requirements for individuals whose work assignments involve exposures to hazardous substances, health hazards, or safety hazards. All such individuals, their supervisors, and management responsible for the site shall receive training meeting the requirements of this section before they are permitted to engage in hazardous waste operations that could expose them to hazardous substances, safety hazards, or health hazards.

Initial Hazardous Waste Operations and Emergency Response (HAZWOPER) training for general site workers is a 40-hour class, but there is a provision in 1910.120(e)(3)(iii) to reduce the length of training to 24 hours in cases where respiratory protection is not required and the hazards are monitored and fully characterized, indicating that exposures are under permissible exposure limits. The hazards associated with CERCLA at K Basins are adequately characterized and monitored and employee exposures are under permissible exposure limits. Therefore, only 24 hours of training is required, unless respiratory protection for chemical hazards is necessary. Use of respirators for protection against exposure to chemical hazards associated with SNF Project CERCLA waste will require 40 hours of training. Employees who are required to wear respirators for protection against radiological hazard (but not chemical hazards) in accordance with Radiological Work Permits, need only 24 hours of HAZWOPER Training. For individuals who have 24 hours of training and need to wear a respirator for protection against exposure to chemical hazards, the additional 16 hours of training can be met with completion of a 16-hour HAZWOPER upgrade course provided by the Hazardous Materials Management and Emergency Response (HAMMER) training facility. Table 7-1 provides training requirements for various circumstances applicable to the SNF Project: 


\begin{tabular}{|c|c|r|}
\hline & DOCUMENT: & HNF-4747 \\
REVISION: & 0 \\
DATE: & $06 / 30 / 99$ \\
PAGE: & 27 \\
\hline
\end{tabular}

TABLE 7-1: HAZWOPER TRATNING REQUIREMENTS

\begin{tabular}{|c|c|c|c|}
\hline Training Requirement & Activity & $\begin{array}{l}0 \\
\frac{9}{3} \\
\frac{3}{3}\end{array}$ & $\frac{a}{3}$ \\
\hline $\begin{array}{l}\text { 24 Hour Initial HAZWOPER Training } \\
\text { 1 Day Supervised Field Experience* } \\
\text { 29 CFR } 1910.120(\mathrm{e})(1) \\
\text { 29 CFR } 1910.120(\mathrm{e})(2) \\
29 \text { CFR } 1910.120(\mathrm{e})(3)(\mathrm{iii}) \\
29 \text { CFR } 1910.120(\mathrm{e})(4)\end{array}$ & $\begin{array}{l}\text { General basin access and work } \\
\text { (assumes the following: } \\
\text { 1. fully monitored and characterized areas, } \\
\text { 2. characterization data showing all exposures } \\
\text { below permissible exposure limits AND } \\
\text { 3. no respirators for chemical hazards required) }\end{array}$ & $\mathbf{X}$ & $\mathbf{X}$ \\
\hline $\begin{array}{l}>\text { 40 Hour Initial HAZWOPER Training } \\
\text { 3 Day Supervised Field Experience* } \\
29 \text { CFR } 1910.120(\mathrm{e})(1) \\
29 \text { CFR } 1910.120(\mathrm{e})(2) \\
29 \text { CFR } 1910.120(\mathrm{e})(3)(\mathrm{i}) \\
29 \text { CFR } 1910.120(\mathrm{e})(4)\end{array}$ & $\begin{array}{l}\text { Wearing respirators } \\
\text { (for purposes of protecting from exposures to } \\
\text { chemical constituents OR work in } \\
\text { uncharacterized areas where exposures may be } \\
\text { above permissible exposure limits ) }\end{array}$ & $\mathbf{X}$ & $\mathbf{X}$ \\
\hline $\begin{array}{l}16 \text { Hour Upgrade Course From 24 Hour } \\
\text { to } 40 \text { Hour Training } \\
29 \text { CFR } 1910.120(\mathrm{e})(1) \\
29 \text { CFR } 1910.120(\mathrm{e})(2) \\
29 \text { CFR } 1910.120(\mathrm{e})(3)(\mathrm{iv})\end{array}$ & $\begin{array}{l}\text { Respiratory Protection needed to protect worker } \\
\text { from exposures to chemical constituents and only } \\
24 \mathrm{hr} \text { HAZWOPER has been completed }\end{array}$ & $\mathbf{X}$ & $\mathbf{X}$ \\
\hline $\begin{array}{l}8 \text { Hour Annual Refresher Training } \\
29 \text { CFR } 1910.120(\mathrm{e})(8)\end{array}$ & Annual Refresher Training & $\mathbf{X}$ & $\mathbf{x}$ \\
\hline $\begin{array}{l}8 \text { Hour Additional Specialized } \\
\text { Supervisor Training } \\
29 \text { CFR 1910.120 (e)(4) }\end{array}$ & Supervising CERCLA Activities & & $\mathbf{X}$ \\
\hline
\end{tabular}

The training requirements of this section apply to employees of FDH, its major subcontractors, lower tier subcontractors, vendors and suppliers who may be onsite, and Federal employees.

\subsection{Elements to be Included in the 40-Hour HAZWOPER Training}

At a minimum, the following topical areas shall be included in the training:

Names of personnel and alternates responsible for site safety and health;

Safety, health, and other hazards present on the site; including the nature and extent of exposures likely as a result of participation in the SNF Project;

Use of PPE;

Work practices by which the employee can minimize risks from hazards; 


\begin{tabular}{|c|c|rr|}
\hline & DOCUMENT: & HNF-4747 \\
REVISION: & 0 \\
DATE: & $06 / 30 / 99$ \\
PAGE: & 28 \\
\hline
\end{tabular}

- Safe use of engineering controls and equipment on the site;

Medical surveillance requirements including recognition of symptoms and signs which might indicate over exposure to hazards; and

The emergency response, confined space entry, and spill containment program elements of the site safety and health plan (Note: This element may also be covered during the Project's on the job training).

\subsection{Initial training}

\subsubsection{General Site Workers}

General site workers engaged in hazardous substance removal or other activities which expose or potentially expose workers to hazardous substances and health hazards shall receive a minimum of 40 hours of instruction, and a minimum of three days actual field experience under the direct supervision of a trained experienced supervisor.

\subsubsection{Infrequent Workers}

Workers on site only occasionally for a specific limited task and who are unlikely to be exposed over permissible exposure limits and published exposure limits shall receive a minimum of 24 hours of instruction off the site, and a minimum of one day actual field experience under the direct supervision of a trained, experienced supervisor.

\subsubsection{Exposures at Less Than Permissible Limits}

Workers regularly on site who work in areas which have been monitored and fully characterized indicating that exposures are under permissible exposure limits and published exposure limits where respirators are not necessary, and the characterization indicates that there are no health hazards or the possibility of an emergency developing, shall receive a minimum of 24 hours of instruction, and a minimum of one day actual field experience under the direct supervision of a trained, experienced supervisor.

\subsubsection{Additional Training}

Workers with 24 hours of training, and who become general site workers or who are required to wear respirators for protection against chemical exposure hazards, shall have the additional 16 hours training and two days of field experience necessary to total the training specified in the foregoing.

\subsection{Management and Supervisor Training}

On-site management and supervisors directly responsible for or who supervise individuals engaged in hazardous waste operations shall receive 40 hours initial and three days of 


\begin{tabular}{|c|c|r|}
\hline & DOCUMENT: & HNF-4747 \\
REVISION: & 0 \\
DATE: & $06 / 30 / 99$ \\
PAGE: & 29 \\
\hline
\end{tabular}

supervised field experience ${ }^{5}$, and at least eight additional hours of specialized training at the time of job assignment on such topics as, but not limited to, the employer's safety and health program, PPE program, spill containment program, and health hazard monitoring procedure and techniques.

\subsection{Trainer Qualifications}

As specified in Subsection 7.1, the Hanford Site Training Program provides the training required in Subsections 7.3 and 7.4. Trainers involved in the training program shall be qualified to instruct employees about the subject matter that is being presented in training. Trainers shall have satisfactorily completed a training program for teaching the subjects they are expected to teach, or they shall have the academic credentials and instructional experience necessary for teaching the subjects. Instructors shall demonstrate competent instructional skills and knowledge of the applicable subject matter.

\subsection{Training Certification}

Employees and supervisors that have received and successfully completed the training and field experience specified in the foregoing subsections shall be certified by their instructor or the head instructor and trained supervisor as having completed the necessary training. A written certificate shall be given to each person certified. Any person who has not been certified or who does not meet the requirements of Subsection 7.8 shall be prohibited from engaging in hazardous waste operations.

Note: The PHMC electronic training database in combination with the training data wallet card, satisfies the OSHA criteria for a written certificate.

\subsection{Emergency Response}

Employees who are engaged in responding to hazardous emergency situations at hazardous waste clean-up sites that may expose them to hazardous substances shall be trained in how to respond to emergencies.

\subsection{Refresher Training}

Employees, managers, and supervisors shall receive eight hours of refresher training annually on the items specified in Subsection 7.2 and/or 7.4 of this section, any critique of incidents that have occurred in the past year that can serve as training examples of related work, and other relevant topics.

\subsection{Visitor Training}

Visitors who are not medically qualified, and who have not received the appropriate training as specified herein, shall not be permitted access to the exclusion and contamination reduction

5 The training may be reduced to 24 hours and one day of supervised field experience if the only area of their responsibility is employees covered by subsections 7.3 .2 and 7.3 .3 


\begin{tabular}{|c|c|c|}
\hline & DOCUMENT: & HNF-4747 \\
REVISION: & 0 \\
DATE: & $06 / 30 / 99$ \\
PAGE: & 30 \\
\hline
\end{tabular}

zones. Visitors who are medically qualified as specified in Section 9.0 of this HASP, and who have hazardous waste and other training as specified in this section may be permitted access to these zones provided they are escorted by a fully trained individual when in these zones. All visitors, irrespective of their individual qualifications, shall receive training in the following subject areas:

The facility emergency evacuation procedures, including audible signals, evacuation routes, and assembly area locations.

Hanford General Employee Training (HGET), General Employee Radiation Training, or visitor/vendor orientation.

Review of the applicable AJHA and RWP.

Work area ALARA guidelines (e.g., low radiation dose rate areas suitable for viewing and observation purposes).

Personal conduct requirements while in support, contamination reduction, and exclusion zones.

\subsection{Additional Training Requirements}

Additional training shall be required for exposures or potential exposures to hazardous substances and conditions not specifically covered by the general training required in the foregoing subsections. At a minimum, this training shall include Radiation Worker I or Radiation Worker II. Additional training that may be required includes the following:

First Aid/Cardiopulmonary Resuscitation (CPR)

Criticality Safety

OSHA required training for specific substances (e.g., asbestos worker, asbestos awareness, lead worker, carcinogens)

Pre-entry briefing on the project/subproject-specific HASP and RWP 


\begin{tabular}{|c|c|r|r|}
\hline & DOCUMENT: & HNF-4747 \\
REVISION: & 0 \\
DATE: & $06 / 30 / 99$ \\
PAGE: & 31 \\
\hline
\end{tabular}

\subsection{PERSONAL PROTECTIVE EQUIPMENT}

The specification of PPE shall be divided into three separate categories; Industrial Safety; Chemical Safety/Industrial Hygiene, and Radiological. In some instances, the existence of two or more hazard categories (e.g., hazardous chemical and radiological) may necessitate special consideration of the PPE ensemble. Such consideration is normally solved by selecting the most conservative ensemble. In certain instances, however, additional consideration may be required, such as exposure to both an airborne organic solvent and airborne radioactive materials. The information contained in Table $8-1$ shall be used as a guide when selecting PPE for specific tasks. Note that PPE Levels A and B protection is not anticipated. 


\begin{tabular}{|c|c|rr|}
\hline & DOCUMENT: & HNF-4747 \\
REVISION: & 0 \\
DATE: & $06 / 30 / 99$ \\
PAGE: & 32 \\
\hline
\end{tabular}

TABLE 8-1: PERSONAL PROTECTIVE EOUIPMENT ENSEMBLES

\begin{tabular}{|c|c|c|}
\hline TYPE OF HAZARD & BASIC PPE & OPTIONAL PPE 6 \\
\hline \multirow[t]{6}{*}{ Industrial/Level D } & Substantial footwear & Steel toed boots \\
\hline & Safety glasses with side shields & Work gloves \\
\hline & Hard hat & Fall arrestor \\
\hline & & $\begin{array}{l}\text { Face shield w/approved } \\
\text { safety glasses and side } \\
\text { shields }\end{array}$ \\
\hline & & Ear plugs/muffs \\
\hline & & Coveralls \\
\hline \multirow{6}{*}{$\begin{array}{l}\text { Hazardous } \\
\text { Chemical Level C }\end{array}$} & Full face piece air purifying respirator & Coveralls (additional) \\
\hline & $\begin{array}{l}\text { Hooded chemical-resistant clothing } \\
\text { (overalls and long-sleeved jacket; } \\
\text { coveralls; one or two-piece chemical- } \\
\text { splash suit; disposable chemical- } \\
\text { resistant overalls). }\end{array}$ & $\begin{array}{l}\text { Chemical resistant, steel toe } \\
\text { and shank outer boots }\end{array}$ \\
\hline & Chemical resistant inner gloves & $\begin{array}{l}\text { Chemical resistant outer } \\
\text { boot covers }\end{array}$ \\
\hline & Chemical resistant outer gloves & Hard hat \\
\hline & & Escape mask \\
\hline & & $\begin{array}{l}\text { Face shield w/approved } \\
\text { safety glasses and side } \\
\text { shields }\end{array}$ \\
\hline $\begin{array}{l}\text { Hazardous } \\
\text { Chemical Level B }\end{array}$ & $\begin{array}{l}\text { Positive pressure, full-face piece self- } \\
\text { contained breathing apparatus (SCBA), } \\
\text { or positive pressure supplied air } \\
\text { respirator with escape SCBA approved } \\
\text { by the National Institute for } \\
\text { Occupational Safety and Health } \\
\text { (NIOSH). }\end{array}$ & Coveralls (additional) \\
\hline
\end{tabular}

6 As specified by the Activity Job Hazard Analysis 


\begin{tabular}{|c|c|r|}
\hline & DOCUMENT: & HNF-4747 \\
REVISION: & 0 \\
DATE: & $06 / 30 / 99$ \\
PAGE: & 33 \\
\hline
\end{tabular}

TABLE 8-1: PERSONAL PROTECTIVE EOUIPMENT ENSEMBLES (Cont.)

TYPE OF HAZARD

Hazardous

Chemical Level B

Hazardous

Chemical Level A
(Cont.)

BASIC PPE

Hooded chemical-resistant clothing

(overalls and long-sleeved jacket;

coveralls; one or two-piece chemical-

splash suit; disposable chemical-

resistant overalls).

Chemical resistant inner gloves

Chemical resistant outer gloves

Chemical resistant, steel toe and shank outer boots

Positive pressure, full face-piece self-

contained breathing apparatus (SCBA),

or positive pressure supplied air

respirator with escape SCBA, approved

by NIOSH.

Totally-encapsulating chemicalprotective suit

Chemical resistant inner gloves

Chemical resistant outer gloves

Chemical resistant, steel toe and shank outer boots

Disposable protective suit, gloves and boots (depending on suit construction, may be worn over totally-encapsulating suit).

Radiological

Contamination

Area

\section{Coveralls}

Surgeon's gloves, or as required by RWP

\section{OPTIONAL PPE 7}

Chemical resistant outer boot covers

Hard hat

Escape mask

Coveralls (additional) .

Long underwear

Hard hat (to be worn under the totally encapsulating suit)

Cotton glove liners

Negative pressure, air purifying, full face piece respirator (as required by RWP)

7 As specified by the Activity Job Hazard Analysis 


\begin{tabular}{|c|c|r|}
\hline & DOCUMENT: & HNF-4747 \\
REVISION: & 0 \\
DATE: & $06 / 30 / 99$ \\
PAGE: & 34 \\
\hline
\end{tabular}

TABLE 8-1: PERSONAL PROTECTIVE EQUTPMENT ENSEMBLES (Cont.)

\begin{tabular}{|c|c|c|}
\hline TYPE OF HAZARD & BASIC PPE & OPTIONAL PPE 8 \\
\hline \multirow{4}{*}{$\begin{array}{l}\text { Radiological } \\
\text { Contamination } \\
\text { Area }\end{array}$} & Gloves, or as required by RWP & $\begin{array}{l}\text { Splash resistant outer } \\
\text { coveralls or suit }\end{array}$ \\
\hline & Shoe covers & \\
\hline & Rubber overshoes & \\
\hline & Hood & \\
\hline \multirow{8}{*}{$\begin{array}{l}\text { Radiological } \\
\text { High } \\
\text { Contamination } \\
\text { Area } \\
\text { Airborne } \\
\text { Radioactivity Area }\end{array}$} & Coveralls - two pairs & Cotton glove liners \\
\hline & Surgeon's gloves, or as required by RWP & coveralls or suit \\
\hline & $\begin{array}{l}\text { Gloves - two pairs, or as required by } \\
\text { RWP }\end{array}$ & \\
\hline & Shoe covers - two pairs & \\
\hline & Rubber overshoes & \\
\hline & Hood & \\
\hline & $\begin{array}{l}\text { Powered Air Purifying Respirator where } \\
\text { airborne concentrations of radioactive } \\
\text { materials is }<100 \text { times the Derived Air } \\
\text { Concentration (DAC) }\end{array}$ & \\
\hline & $\begin{array}{l}\text { Supplied Air Respirator with Self } \\
\text { Contained Breathing Apparatus where } \\
\text { airborne concentrations of radioactive } \\
\text { materials is }>100 \text { times the DAC }\end{array}$ & \\
\hline
\end{tabular}

The PPE ensembles specified in Table 8- 1 are to used as guides, and should be viewed as standard minimum requirements. Actual PPE selection shall be based on detailed (AJHA) evaluation of the hazards associated with work activities. Existing mechanisms shall be used to implement and communicate PPE requirements to the effected work force, such as the RWP. Used and non-disposable PPE shall be laundered after each use, to ensure adequate contamination control.

${ }^{8}$ As specified by the Activity Job Hazard Analysis 


\begin{tabular}{|c|c|r|}
\hline & DOCUMENT: & HNF-4747 \\
REVISION: & 0 \\
DATE: & $06 / 30 / 99$ \\
PAGE: & 35 \\
\hline
\end{tabular}

\subsection{MEDICAL SURVEILLANCE}

Medical examinations, consultations, and determinations are conducted by the Hanford Environmental Health Foundation (HEHF). HEHF has an established occupational medicine program, with attending physicians who are qualified in the practice of occupational medicine and who are familiar with the requirements of 29 CFR 1910.120. The HEHF physicians are also familiar with the types of hazards routinely encountered at the Hanford Site. The content and extent of medical examinations and consultations are based on an evaluation of the hazards to which the employee is, or can reasonably be expected to be, exposed. The method for determining the hazards associated with any given individual's job function is the completion of the Employee Job Task Analysis (EJTA). The EJTA is a computer-based questionnaire that identifies substances and actions involved with individual work assignments. The electronic version of the completed and approved EJTA is automatically reviewed by HEHF staff. The affected individuals are then scheduled by HEHF for the appropriate medical examinations. The following medical surveillance program requirements are based on this existing system.

\subsection{Frequency}

Medical examinations shall be conducted:

- Prior to an individual's project assignment involving hazardous substances or work conditions;

- At least once every 12 months for each affected individual (this requirement may be relaxed to biennially at the physician's discretion);

- Upon termination of employment or reassignment to an area not requiring comparable medical surveillance ${ }^{9}$;

- As soon as possible upon notification by an employee that the employee has developed signs or symptoms indicating possible overexposure to hazardous substances or health hazards;

- As soon as possible after the employee has been injured or exposed above the permissible exposure limits or published exposure levels in an emergency situation; and

- At more frequent times, if the examining physician determines that an increased frequency of examination is medically necessary. 9 This requirement may be waived, if the individual has undergone a medical examination less than 6 . months prior to the
termination or reassignment. 


\begin{tabular}{|c|c|r|}
\hline & DOCUMENT: & HNF-4747 \\
REVISION: & 0 \\
DATE: & $06 / 30 / 99$ \\
PAGE: & 36 \\
\hline
\end{tabular}

\subsection{Medical Examination Content}

Medical examinations conducted by HEHF include a medical and work history (or updated history if one is already in the individual's file) with special emphasis on symptoms related to the handling of hazardous substances and health hazards, and to fitness for duty, including the ability to wear any required PPE under extreme conditions (e.g., temperature extremes) that may be expected at the work site.

\subsection{Information to be Supplied to the Examining Physician}

The EJTA provides sufficient information to the examining physician to satisfy the requirements of 29 CFR $1910.120(\mathrm{f})(6)$. The EJTA may not, however, cover non-routine or unusual hazards and/or hazard controls. To preclude inadvertent omission of a medical surveillance requirement in such instances, line management in cooperation with the SHSO shall review AJHAs and new work/task assignments for special exposure conditions which might have non-routine medical surveillance requirements (e.g., OSHA vertical standard requirements) prior to initiation of the task or assignment of the individual.

\subsection{Information to be Supplied by the Examining Physician}

HEHF provides Hanford Site employers with opinions as to whether the employee has any detected medical conditions which would place the employee at increased risk of material impairment of the employee's health from work in hazardous waste operations or emergency response, or from respirator use. Based on this opinion, the examining physician may recommend work (e.g., lifting or other such heavy labor) or hazard control (e.g., use of respirators) restrictions. Information supplied by the examining physician shall not include specific findings or diagnoses unrelated to occupational exposure. The examining physician shall also include a statement that the individual has been informed by the physician of the results of the medical examination and any medical conditions that require further examination or treatment. Restrictions recommended by the examining physician shall be implemented by the Project.

\subsection{Information to be Supplied to the Employee}

Upon request, all information relating to the medical examination, including all test results, shall be provided to the individual for retention.

\subsection{Recordkeeping}

HEHF maintains records of medical examinations and consultations in accordance with the requirements of 29 CFR $1910.120(f)(8)$. 


\begin{tabular}{|c|c|c|}
\hline & DOCUMENT: & HNF-4747 \\
REVISION: & 0 \\
DATE: & $06 / 30 / 99$ \\
\hline & PAGE: & 37 \\
\hline
\end{tabular}

\subsection{Other Medical Providers}

Medical providers other than HEHF may be used. The examining physician's protocols, test results and findings must, however, be reviewed and concurred with by HEHF before the individual is authorized to begin onsite work on the project. 


\begin{tabular}{|c|c|rr|}
\hline & DOCUMENT: & HNF-4747 \\
\hline & KEASINS INTERIM REMEDIAL ACTION & REVION: \\
DATE: & $06 / 30 / 99$ \\
PEAGE: & 38 \\
\hline
\end{tabular}

\subsection{MONITORING}

Monitoring is divided into three substance/condition categories: radiological, chemical, and other. The following subsections specify minimum monitoring requirements for each category.

\subsection{Radiological}

The radiological monitoring category is further divided into the following subcategories:

\subsubsection{Personnel Monitoring}

Personnel monitoring shall be performed for external radiation exposures (external dosimetry), and for uptake of radioactive materials into the body (internal dosimetry).

Routine external radiation monitoring shall be conducted for all individuals whose job functions have a potential for whole body exposures of more than $100 \mathrm{mrem} / \mathrm{year}$; or more than $5 \mathrm{rem} /$ year to the skin, extremities, or a deep dose to any individual organ or tissue other than the lens of the eye; and more than $1.5 \mathrm{rem} /$ year to the lens of the eye. Assignment of dosimeters, and frequency of dosimeter exchange, shall comply with the provisions of HNF-PRO-379 (PHMC98F) and HNF-PRO-320 (PHMC98G).

Routine internal radiation exposure monitoring shall be conducted for all individuals whose job functions have a potential to receive intakes resulting in a committed effective dose equivalent of $100 \mathrm{mrem} /$ year or more. Routine internal dosimetry may consist of any combination of excreta analysis (bioassays), and in vivo analysis (whole body and/or lung counting). Determination of the type of bioassay and/or in vivo analysis required, the monitoring frequency, and action or trigger levels shall comply with the provisions of HNF-PRO-380 (PHMC98H).

Routine breathing zone air sampling for airborne radioactive materials may be conducted at the discretion of the SHSO, or designee. Breathing zone air sampling results shall be used to document the effectiveness of the respiratory protection and bioassay programs.

\subsubsection{Area Monitoring}

Physical surveys shall be conducted to assess direct radiation levels, surface contamination levels and airborne contamination levels. The frequency of each type of survey shall be based on potential radiological conditions, probability of change in conditions, and occupancy factors. Routine surveys shall be conducted to facilitate tracking and trending of radiological conditions in work axeas. Special surveys may be conducted as conditions dictate (e.g., to assess the nature and extent of spills, to document the effectiveness of decontamination, etc.). Area monitoring shall be conducted in accordance with the provisions of HNF-PRO-435 (PHMC97L). 


\begin{tabular}{|c|c|r|}
\hline & DOCUMENT: & HNF-4747 \\
REVISION: & 0 \\
DATE: & $06 / 30 / 99$ \\
PAGE: & 39 \\
\hline
\end{tabular}

\subsubsection{Special Surveys}

Several different types of personnel monitoring may be conducted for unusual or nonroutine circumstances. These circumstances include potential skin contamination, potential accidental intake of radioactive materials, potential direct radiation exposure in excess of established action levels and/or limits, and injuries involving potentially contaminated items (e.g., puncture wounds by contaminated articles). Surveys that support assessment of potential unanticipated exposure shall adhere to the provisions of HNF-PRO-688 (PHMC98I), HNF-PRO-384 (PHMC98J), and HNF-PRO-380 (PHMC98H).

\subsection{Chemical}

The preliminary hazard assessment does not indicate a need to conduct personnel monitoring for hazardous substances or materials. The need for monitoring, however, will be periodically evaluated as site and work area conditions change (i.e., during construction activities). Determination of need will be identified through assessment of the applicable MSDS and the AJHA. Monitoring methods, frequencies, and action levels will be specified by the SHSO.

Types of monitoring may include organic vapor monitor with both the $10.6 \mathrm{eV}$ and $11.7 \mathrm{eV}$ lamps, organic vapor analyzer, combustible gas indicator/oxygen meter, calorimetric detector tubes for semi-quantitative assessments of gases and vapors, and $\mathrm{pH}$ meters. Personal Air Monitors (badges) and breathing zone air sampling may be used at the discretion of the SHSO.

\subsection{Other}

Other types of monitoring which may be required include special radiation monitoring for declared pregnant workers, heat stress monitoring, lighting levels, and noise. Special radiation monitoring for declared pregnant workers shall include the following constraints:

Immediately after the pregnancy has been declared, determine the radiation exposure since the estimated date of conception.

The radiation exposure to the fetus shall be limited to a total of 500 mrem for the full term of the pregnancy.

WARNING: If the worker has received 500 or more mrem since conception at the time of declaration, the worker shall not be assigned to areas wherein additional occupational radiation exposure might occur.

Reasonable efforts shall be made to limit the worker's exposure rate to not more than $50 \mathrm{mrem} / \mathrm{month}$. 


\begin{tabular}{|c|c|c|}
\hline & DOCUMENT: & HNF-4747 \\
REVISION: & 0 \\
DATE: & $06 / 30 / 99$ \\
PAGE: & 40 \\
\hline
\end{tabular}

An assessment of the need for other types of monitoring (heat stress, noise, and lighting levels) shall be conducted via the AJHA. Monitoring will be initiated whenever the AJHA indicates that a hazard may exist. The SHSO shall determine the appropriate monitoring methods and frequencies. Action levels are specified either by procedure (HNF-PRO-121 for heat stress) or become OSHA permissible exposure limits (PELs)/NIOSH TLVs by default. 


\begin{tabular}{|c|c|c|}
\hline & DOCUMENT: & HNF-4747 \\
REVISION: & 0 \\
DATE: & $06 / 30 / 99$ \\
PAGE: & 41 \\
\hline
\end{tabular}

\subsection{SITE CONTROL}

As indicated in previous sections, the $\mathrm{K}$ Basins have an established and mature hazards control program. The highest potential exposure and related risks result from the radioactive materials present in the basins, and as contamination on facility surfaces. As a consequence, existing methodology for the establishment of contamination areas, high contamination areas, radiation areas, high radiation areas, very high radiation areas, airborne radioactive materials areas, and radiological buffer zones will be used in lieu of exclusion zones, buffer zones, and support zones. The following relationship between the existing site control program and the requirements of 29 CFR 1910.120 is provided for reference and clarity.

Exclusion Zone: The exclusion zone is defined as an inner work area where this is a probability of exposure. Any area designated as a radiation area, high radiation area, very high radiation area, contamination area, high contamination area, airborne radioactive materials, or airborne hazardous materials area shall be similarly designated as the Exclusion Zone.

Buffer Zone: $\quad$ The Buffer Zone is an area immediately adjacent to (and usually surrounding) the Exclusion Zone. The purpose of the Buffer Zone is to control the spread of contamination and personnel exposures to radiation. The Buffer Zone shall be equivalent to the radiological buffer zone

Support Zone: $\quad$ The Support Zone is an area immediately adjacent to the controlled area boundary, but within the site boundary. The purpose of the support zone is to aid in job preparation and support (e.g., materials and equipment staging and short-term storage).

Given that contamination and radiation zone demarcations frequently expand and contract to accommodate specific tasks, exact definition of the $\mathrm{K}$ Basin zones is not warranted in this HASP. Instead, the normal PHMC work planning process shall establish these zones as required for specific tasks/subprojects. (A large map of the facility is posted at the entry way that shows the current (updated daily) conditions with respect to these various zones. Individuals are required to review this map prior to entry into any of the work areas.) The following minimum requirements, however, shall apply to the construction and use of these zones, irrespective of actual boundaries.

The Access Control/Entry System at the K Basins will be used to ensure that the HAZWOPER training requirement is met for any individual who requires unescorted access into the basins and has the potential to be exposed to hazardous substances. 


\begin{tabular}{|c|c|c|}
\hline & DOCUMENT: & HNF-4747 \\
REVISION: & 0 \\
DATE: & $06 / 30 / 99$ \\
PAGE: & 42 \\
\hline
\end{tabular}

- Zone boundaries shall be clearly and unmistakably marked and posted, such that inadvertent entry is precluded.

- Mechanisms shall be included to allow workers to doff PPE and exit the zone without spreading contamination (e.g., step off pads and survey stations).

- All personnel authorized entry into a particular zone shall be trained on entry qualifications and requirements.

- Physical control devices shall be used to prevent inadvertent entry into high hazard areas (e.g., high radiation areas and very high radiation areas). Such physical controls shall be designed in such a manner that will not preclude an individual from exiting the high hazard area. 


\begin{tabular}{|c|c|cr|}
\hline & DOCUMENT: & HNF-4747 \\
REVISION: & 0 \\
DATE: & $06 / 30 / 99$ \\
PAGE: & 43 \\
\hline
\end{tabular}

\subsection{DECONTAMINATION}

Radioactive materials represent the predominant contamination potential at the K Basins. Potential contamination by non-radiological hazardous substances will be addressed by the AJHA prior to task execution.

Precautions are routinely exercised to avoid skin contamination by radioactive materials. These precautions start with personnel training (HGET, Radiation Worker I, and Radiation Worker II), continue with the use of PPE ensembles designed to act as a barrier between the worker and the contamination, and conclude with physical surveys conducted during and after doffing of PPE. The major deviation between the methods used for protection against contamination required by 29 CFR $1910.120(\mathrm{k})$, and those employed for radioactive materials, is the routine decontamination of PPE prior to doffing.

Should skin contamination occur, decontamination and the radiation dose assessment resulting from the contamination, shall be conducted in accordance with HNF-IP-0718 (HNF98A) and HNF-PRO-384 (PHMC98J), respectively.

WARNING: Serious personal injury takes priority over decontamination procedures. Do not attempt personal decontamination if the injury will be aggravated. An injured person should first be removed from immediate danger. Then, if it is determined to be necessary by the SHSO and the radiological control technician (RCT), decontamination may be accomplished prior to leaving the site for medical treatment. Emergency decontamination facilities are located at the $100 \mathrm{~N}$. Area, the 222-S Building, and at the Kadlec Medical Center. If the extent of the personal injury is unknown, emergency response personnel (i.e., the Hanford Fire Department) will make the decision to move the injured person. The RCT and the SHSO may be required to escort the injured person to the hospital.

Decontamination shall be required any time that contamination monitoring indicates detectable radioactivity. Table $12-1$ provides the maximum permitted detection levels.

If future operations require the use of hazardous substances such that a PPE ensemble equivalent to Level B or greater (see Section 8.0, Table 8-1 for a description of PPE ensembles) is required, decontamination procedures shall become mandatory. The following decontamination elements shall be included in the decontamination procedures:

C Written procedures shall be developed to minimize worker exposure to hazardous substances, and to effectively conduct decontamination.

Each individual leaving the exclusion zone shall be decontaminated. 


\begin{tabular}{|c|c|r|}
\hline & DOCUMENT: & HNF-4747 \\
REVISION: & 0 \\
DATE: & $06 / 30 / 99$ \\
PAGE: & 44 \\
\hline
\end{tabular}

- Decontamination methods and materials shall be determined by the SHSO during the job planning phase.

- The location of the decontamination station shall be at the border of the exclusion zone and the buffer zone ${ }^{10}$.

- Decontamination procedures shall be communicated to involved individuals, including all individuals who may assist in personnel decontamination.

- Hazardous chemical decontamination materials and PPE shall either be properly disposed of, or decontaminated such that unprotected handling will not further expose individuals to hazardous substances.

- Decontamination practices shall be monitored by the SHSO to determine their effectiveness. When such practices are found to be ineffective, appropriate steps shall be taken to correct any deficiencies.

\footnotetext{
${ }^{10}$ The decontamination station shall be located so as to minimize exposure to airborne hazardous substances by individuals located in the buffer zone.
} 


\begin{tabular}{|c|c|r|}
\hline & DOCUMENT: & HNF-4747 \\
REVISION: & 0 \\
DATE: & $06 / 30 / 99$ \\
PAGE: & 45 \\
\hline
\end{tabular}

TABLE 12-1

SUMMARY OF CONTAMINATION VALUES

TOTAL

\begin{tabular}{|c|c|c|}
\hline RADIONUCLIDE ${ }^{11}$ & $\begin{array}{l}\text { REMOVABLE } \\
\left(\mathrm{dpm} / 100 \mathrm{~cm}^{2}\right)^{12}\end{array}$ & $\begin{array}{c}\text { (FIXED + REMOVABLE) } \\
\left(\mathrm{dpm} / 100 \mathrm{~cm}^{2}\right)^{13}\end{array}$ \\
\hline $\begin{array}{l}\text { U-Natural, U-235, U-238 \& } \\
\text { associated decay products }\end{array}$ & 1,000 alpha & 5,000 alpha \\
\hline $\begin{array}{l}\text { Transuranics, Ra-226, Ra-228, } \\
\text { Th-230, Th-228, Pa-231, Ac-227, } \\
\text { I-129 }\end{array}$ & 20 & 500 \\
\hline $\begin{array}{l}\text { Th-Natural, Th-232, Sr-90, Ra-223, } \\
\text { Ra-224, U-232, I-125, I-126, I-131, } \\
\text { I-133 }\end{array}$ & 200 & 1,000 \\
\hline $\begin{array}{l}\text { Beta-gamma emitters (decay modes } \\
\text { other than alpha emission or } \\
\text { spontaneous fission) except Sr-90 } \\
\text { and other noted above. Includes } \\
\text { mixed fission products containing } \\
\text { Sr-90. }\end{array}$ & 1,000 beta-gamma & 5,000 beta-gamma \\
\hline $\begin{array}{l}\text { Tritium organic compounds, } \\
\text { surfaces contaminated by HT, } \\
\text { HTO }^{14} \text { and metal tritide aerosols }\end{array}$ & 10,000 & 10,000 \\
\hline
\end{tabular}

\footnotetext{
${ }^{11}$ The values in this table apply to radioactive material contamination deposited on, but not incorporated into the interior of the contaminated item. Where contamination by both alpha- and beta-gamma-emitting radionuclides exists, the limits established for the alpha- and beta-gamma-emitting radionuclides apply independently.

${ }^{12}$ The amount of removable radioactive material per $100 \mathrm{~cm}^{2}$ of surface area should be determined by swiping the area with a dry filter or soft absorbent paper while applying moderate pressure and then assessing the amount of radioactive material on the swipe with an appropriate instrument of known efficiency. For objects with a surface area less than $100 \mathrm{~cm}^{2}$, the entire surface areas should be swiped, and the activity per unit area should be based on the actual surface area. Except for transuranics, Ra-228, Ac-227, Th-228, Th-230, Pa-231 and alpha emitters, it is not necessary to use swiping techniques to measure removable contamination levels if direct scan surveys indicate that the total residual contamination levels are below the values for removable contamination.

${ }^{13}$ The levels may be averaged over a square meter provided the maximum activity in any area of $100 \mathrm{~cm}^{2}$ is less than three times the values shown in this table.

$14 \mathrm{HT}$ is a hydrogen atom bonded with a tritium atom. HTO is water where one hydrogen atom is replaced with a tritium atom.
} 


\begin{tabular}{|c|c|c|}
\hline & DOCUMENT: & HNF-4747 \\
REVISION: & 0 \\
DATE: & $06 / 30 / 99$ \\
PAGE: & 46 \\
\hline
\end{tabular}

\subsection{EMERGENCY RESPONSE}

The Hanford Site has a mature and sophisticated emergency response program. This program is described in DOE/RL-94-02, Hanford Emergency Response Plan, Revision 1, implemented by DOE-0223, Emergency Plan Implementing Procedures, April 1997. This program is further refined by the PHMC in HNF-PRO-424, Emergency Preparedness Program (PHMC98K). At an even lower level the K Basins has developed a Building Emergency Plan (BEP) to accommodate facilityspecific hazards, evacuation routes and assembly areas. In their aggregate, these documents fully satisfy the requirements of 29 CFR 1910.120 (I) for an emergency response plan.

The following minimum requirements shall be adhered to in order to ensure that emergency actions will be effective in the protection of personnel involved in the $\mathrm{K}$ Basins Interim Remedial Action:

- Prior to working on the Project, personnel will review applicable plans and procedures, demonstrate that they are familiar with emergency alarms, and attend pre-job safety meetings. Pre-job safety meetings shall be conducted to discuss project-specific hazards; and the appropriate emergency response, including precautions specifically addressing individuals in PPE or individuals who may be potentially contaminated, evacuation routes, and notifications.

- If an emergency or abnormal event occurs, or an alarm annunciates that requires emergency egress, individuals will evacuate the effected area or building, and communicate the abnormal condition to the Patrol Operations Center (911, or 373-3800 by cellular telephone) and the Building Emergency Director (BED).

- The BED or designated alternate(s) has overall responsibility for implementing emergency procedures, to mitigate an emergency, and all other responsibilities designated in the emergency implementing procedures.

- The BED has the authority to commit all necessary resources (personnel, equipment, and materials) to respond to any emergency ${ }^{15}$.

- Upon notification of an abnormal incident (e.g., release of hazardous material), the BED will notify necessary emergency resources, if required, and will ensure all other required notifications are completed.

- The BED will respond to a declared emergency to mitigate the incident using emergency response plan implementing procedures, to ensure effective decision making (e.g., ensure that effective mitigative actions are initiated), and to initiate recovery actions.

\footnotetext{
15 Authority to act in the BED's absence or during periods when the BED is otherwise occupied, has been delegated to the Hanford Fire Department and the Hanford Patrol, including acting as incident commanders.
} 


\begin{tabular}{|c|c|r|}
\hline & DOCUMENT: & HNF-4747 \\
\hline & K BASINS INTERIM REMEDIAL ACTION & 0 \\
HEALTH AND SAFETY PLAN & DATE: & $06 / 30 / 99$ \\
\hline
\end{tabular}

Emergency telephone and pager numbers are provided in Table 13-1. Alarm descriptions and general emergency instructions are illustrated in Figure 13-1.

TABLE 13-1: EMERGENCY CONTACT INFORMATION

\begin{tabular}{|c|c|}
\hline FUNCTION & TELEPHONE/PAGER NUMBER \\
\hline $\begin{array}{l}\text { Emergency Services } \\
\text { Patrol/Fire/Ambulance }\end{array}$ & Land Line :.....................911 \\
\hline Hanford Fire Department (non-emergency) & $373-2745$ \\
\hline First Aid $(200-W)$ & $373-2714$ \\
\hline PNNL Exposure Evaluator & $376-2222$ \\
\hline Building Emergency Director - K East & $373-1777$ \\
\hline Alternate BED - K East & $373-1330$ \\
\hline Building Emergency Director - K West & 373-3422 \\
\hline Alternate BED - K West & $373-4927$ \\
\hline
\end{tabular}

FIGURE 13-1

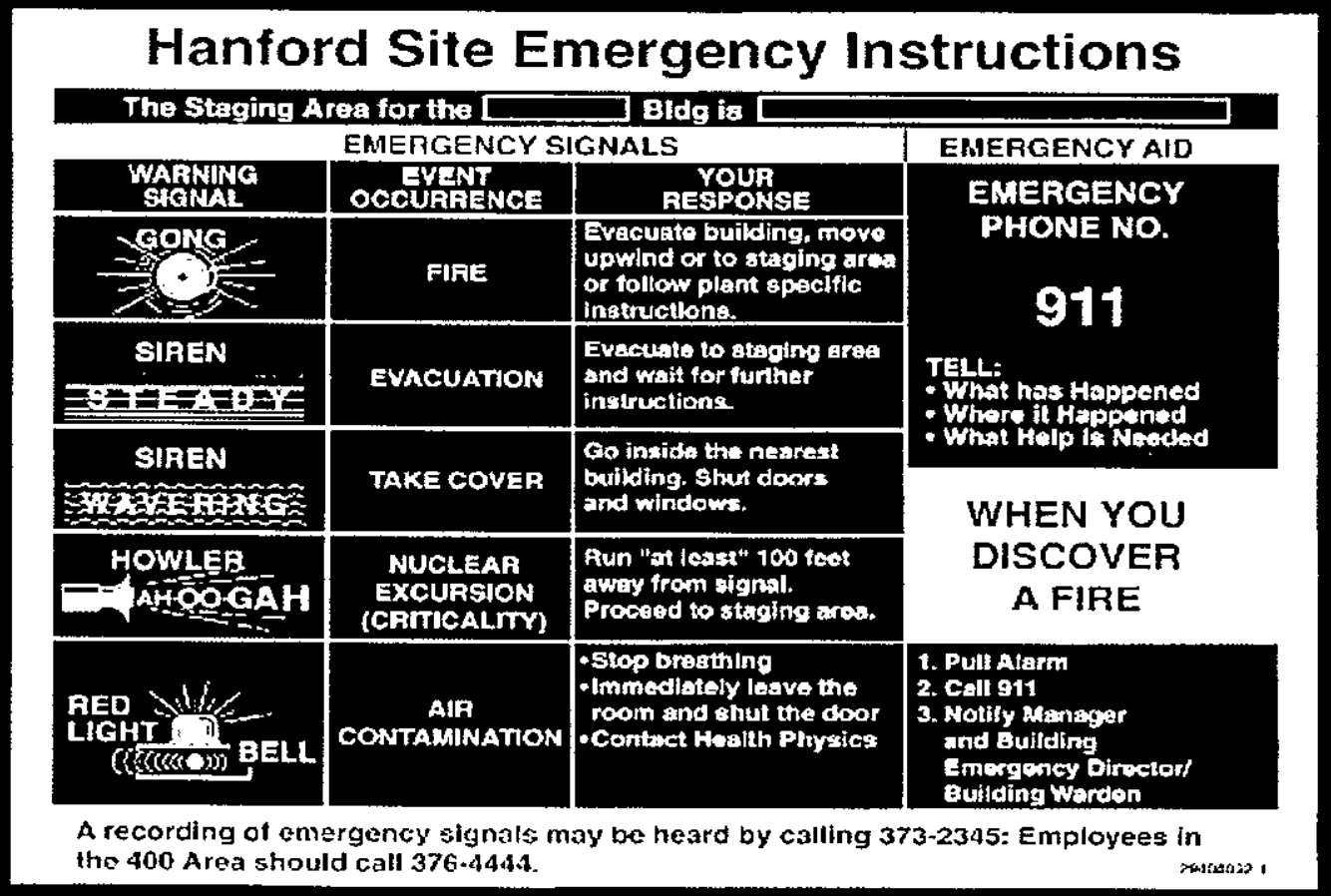




\begin{tabular}{|c|c|r|}
\hline & DOCUMENT: & HNF-4747 \\
\hline & KEVISION: & 0 \\
DATE: & $06 / 30 / 99$ \\
PAGE: & 48 \\
\hline
\end{tabular}

\subsection{CONFINED SPACE ENTRIES}

Confined space entries shall be conducted in accordance with HNF-PRO-110 (PHMC97C), Confined Space. Therein, the term "confined space" is subcategorized into permit required and non-permit confined spaces. HNF-PRO-110 procedures meet the intent of 29 CFR 1910.146, Permit-Required Confined Spaces. The following sequence of events shall be adhered to whenever there is a potential for a confined space entry dictated by the detailed work plan:

Walk down the work area(s) specified in the work plan.

Locate and identify any area which has already been classified as a confined space or which may be classified as a confined space.

Identify confined space entry as a hazard when completing the AJHA.

Prepare a confined space entry permit, if required.

$r$ Ensure that all involved personnel are properly trained and qualified.

Ensure that the proper notifications have been made (e.g., the Hanford Fire Department), if required.

- Complete a survey of the confined space prior to the entry to determine the presence or absence of hazardous substance and vapors, the presence/absence of adequate levels of oxygen, and the presence/absence of physical hazards.

The SHSO shall monitor all permit-required confined space entries to ensure compliance with all of the applicable requirements of HNF-PRO- 110. 


\begin{tabular}{|c|c|r|}
\hline & DOCUMENT: & HNF-4747 \\
REVISION: & 0 \\
DATE: & $06 / 30 / 99$ \\
PAGE: & 49 \\
\hline
\end{tabular}

\subsection{SPILL CONTAINMENT PROGRAM}

The Project shall use engineered containment systems whenever practical to ensure that significant amounts of hazardous materials do not escape their primary containment. When it becomes impractical to use engineered containment controls, the Project shall implement the following:

Prepare written procedures specifying minimum requirements for the containment of spills, the recovery of spilled materials, the decontamination of areas/equipment affected by the spilled material and the materials and equipment used in the recovery process, and the proper disposal of recovered and contaminated materials and equipment.

Ensure that individuals are trained in the safe recovery of spilled materials, and that only qualified individuals are assigned to spill recovery tasks.

Ensure that sufficient materials are at or near the work location to contain the entire volume of materials at risk, plus any materials used in the recovery process (e.g., absorbents and mops). 


\begin{tabular}{|c|c|r|}
\hline & DOCUMENT: & HNF-4747 \\
REVISION: & 0 \\
DATE: & $06 / 30 / 99$ \\
PAGE: & 50 \\
\hline
\end{tabular}

\subsection{PRE-ENTRY BRIEFINGS}

A pre-entry or pre-job briefing shall be conducted prior to initiating any new activity, and at such other times as necessary to ensure that employees are apprised of hazards and/or changes which may affect safety. The pre-entry briefing shall cover the following minimum topics:

The scope and details of work to be performed.

The identified hazards associated with, and/or caused by, the work and the environment within which the work is conducted.

Physical and/or administrative hazard controls implemented for the work activity, including specified PPE.

The required use of any non-routine personnel monitoring equipment, devices, or routines.

c Any special permits prepared for the work activity (e.g., confined space, hot work, and electrical work).

Any changes in routes of access and egress that may be necessitated by the work activity. 


\begin{tabular}{|c|c|c|}
\hline & DOCUMENT: & HNF-4747 \\
REVISION: & 0 \\
DATE: & $06 / 30 / 99$ \\
PAGE: & 51 \\
\hline
\end{tabular}

\subsection{HAZARD COMMUNICATION PROGRAM}

The PHMC has a robust hazard communication program as defined in HNF-PRO-578 (PHMC97M), which conforms to the requirements of 29 CFR 1910.1200. The Hazard Communication program includes a variety of communication methods, including MSDS, vendor labeling, and area posting. In addition, the Hanford Hazard Label is used to further communicate hazards to using individuals. The Hanford Hazard Label is color coded as follows:

Health Hazard................ blue

Fire Hazard.................. red

Reactivity Hazard........... yellow

Other Hazard................. white

Next to the color coded area on the Hanford Hazard label is a box reserved for the hazard severity code, indicated as follows:

$0 \ldots \ldots \ldots \ldots . . . .$. Minimal or no hazard

1 .................Slight hazard

2..................Moderate hazard

3.................Serious hazard

4.................Severe hazard

Individuals who have or may have occasion to use hazardous substances shall receive documented facility- and job-specific hazard training. Training formats may include formal HAZWOPER, pre-job briefings, and/or team safety meetings as described in the foregoing. 


\begin{tabular}{|c|c|r|}
\hline & DOCUMENT: & HNF-4747 \\
REVISION: & 0 \\
DATE: & $06 / 30 / 99$ \\
PAGE: & 52 \\
\hline
\end{tabular}

\subsection{PROGRAM EFFECTIVENESS}

The SHSO or designee shall conduct periodic inspections to assess the effectiveness of Project HASPs. This shall include this HASP and any sub-tier HASPs developed for specific subprojects or tasks. Such inspection shall be separate from any other form of self-assessment that may be conducted by the Project. 


\begin{tabular}{|c|c|r|r|}
\hline & DOCUMENT: & HNF-4747 \\
REVISION: & 0 \\
DATE: & $06 / 30 / 99$ \\
PAGE: & 53 \\
\hline
\end{tabular}

\subsection{REFERENCES}

DOE93A:

Title 10, Code of Federal Regulations, Part 835, Occupational Radiation Protection, as amended.

DOE96A:

DOE-RL, Hanford Site Radiological Control Manual, HSRCM-1, as amended, U.S. Department of Energy, Richland Operations Office, Richland Washington.

DOE98A:

Focused Feasibility Study for the K Basins Interim Remedial Action, DOE/RL-98-66, Draft Revision A, November 1998

FDH99A: $\quad$ The Spent Nuclear Fuel Project, Project Execution Plan, HNF-3552, Revision 0, February 18, 1999

HNF98A:

HNF-IP-0718, Health Physics Technical Practices and Procedures, Revision 0, Change 3, 8/31/1998

OSHA99A:

Title 29, Code of Federal Regulations, Part 1910, Occupational Safety and Health Standards, as currently amended.

PHMC98A: $\quad$ Project Hanford Procedure HNF-PRO-079, Revision 2, 07/29/98, Job Hazard Analysis

PHMC98B: $\quad$ Project Hanford Procedure HNF-PRO-088, Revision 2, 09/18/98, Electrical Work Safety

PHMC98C: $\quad$ Project Hanford Procedure HNF-PRO-356, Revision 1, 7/16/98, Controlling Hotwork

PHMC98D: $\quad$ Project Hanford Procedures, HNF-PRO-1623, Revision 0, 09/01/98, Radiological Work Planning Process

PHMC98E: $\quad$ Project Hanford Procedure, HNF-PRO-2258, Revision 0, 08/31/98, Chemical Management

PHMC98F: $\quad$ Project Hanford Procedure, HNF-PRO-379, Revision 2, 11/10/98, External Dosimetry Program

PHMC98G: $\quad$ Project Hanford Procedure, HNF-PRO-320, Revision 2, 03/01/98, Personal Nuclear Accident Dosimetry 


\begin{tabular}{|c|c|r|}
\hline & DOCUMENT: & HNF-4747 \\
REVISION: & 0 \\
DATE: & $06 / 30 / 99$ \\
PAGE: & 54 \\
\hline
\end{tabular}

PHMC98H: $\quad$ Project Hanford Procedure, HNF-PRO-380, Revision 1, 03/20/98, Internal Dosimetry Program

PHMC981: $\quad$ Project Hanford Procedure, HNF-PRO-688, Revision 1, 03/20/98, External Dosimetry Investigations

PHMC98j: $\quad$ Project Hanford Procedure, HNF-PRO-384, Revision 1, 03/20/98, Skin Contamination Dose Assessment

PHMC98K: $\quad$ Project Hanford Procedure, HNF-PRO-424, Revision 2, 07/21/98, Emergency Preparedness Program

PHMC97A: $\quad$ Project Hanford Procedure, HNF-PRO-408, Revision 0, 09/30/97, Asbestos - Facility Management/General Industry

PHMC97B: $\quad$ Project Hanford Procedure, HNF-PRO-584, Revision 0, 07/01/97, Bloodborne Pathogens

PHMC97C: $\quad$ Project Hanford Procedure, HNF-PRO-110, Revision 0, 07/01/97, Confined Space

PHMC97D: $\quad$ Project Hanford Procedure, HNF-PRO-092, Revision 1, 07/01/97, Fall Protection

PHMC97E: $\quad$ Project Hanford Procedure, HNF-PRO-359, Revision 0, 08/01/97, Control of Combustible

PHMC97F: $\quad$ Project Hanford Procedure, HNF-PRO-358, Revision 0, 08/01/97, Flammable/Combustible Liquids

PHMC97G: $\quad$ Project Hanford Procedure, HNF-PRO-355, Revision 0, 08/01/97, Portable Heaters

PHMC97H: $\quad$ Project Hanford Procedure,HNF-PRO-115, Revision 0, 07/01/97, Hearing Conservation

PHMC97I: $\quad$ Project Hanford Procedure, HNF-PRO-081, Revision 2, 09/30/97, Hazardous Energy Control Program

PHMC97): $\quad$ Project Hanford Procedure, HNF-PRO-121, Revision 0, 07/01/97, Heat Stress Control 


\begin{tabular}{|c|c|cr|}
\hline & DOCUMENT: & HNF-4747 \\
REVISION: & 0 \\
DATE: & $06 / 30 / 99$ \\
PAGE: & 55 \\
\hline
\end{tabular}

PHMC97K: $\quad$ Project Hanford Procedure, HNF-PRO-091, Revision 1, 07/01/97, Walking/Working Surfaces

PHMC97L: $\quad$ Project Hanford Procedure, HNF-PRO-435, Revision 0, 09/08/97, Required Radiological Surveillances

PHMC97M: $\quad$ Project Hanford Procedure, HNF-PRO-578, Revision 1, 09/30/97, Hazard Communication 


\section{CORRESPONDENCE DISTRIBUTION COVERSHEET}

Author

N. H. Williams

P. T. Day $376=4827$
Addressee

P. G. Loscoe

RI
Correspondence No. FDH-9954434

June 30, 1999

CONTRACT NUMBER DE-AC06-96RL13200 - ISSUANCE OF THE SPENT

Subject: NUCLEAR FUEL PROJECT HEALTH AND SAFETY PLAN FOR THE K BASNS INTERIM REMEDIAL ACTION PROJECT, HNF-4747, REVISION 0

\section{DISTRIBUTION}

\begin{tabular}{|c|c|c|c|c|}
\hline Approval & Date & Name & Location & w/att. \\
\hline & & Correspondence Control & A3-01 & $X$ \\
\hline & & \multicolumn{3}{|l|}{ Eluor Daniel Hanford, Inc. } \\
\hline & & President's Office & $\mathrm{H} 5-20$ & \\
\hline & & W. D. Adair & $\mathrm{H} 6-21$ & \\
\hline & & D. L. Jackson & H6-32 & \\
\hline & & V.S. Mitchell & H6-32 & \\
\hline & & R. J. Swan & H6-23 & \\
\hline & & W. E. Toebe & H6-23 & \\
\hline & & \multicolumn{3}{|l|}{ Spent Nuclear Fuel Project } \\
\hline & & P.S. Blair & R3-11 & \\
\hline$x \otimes$ & $X 6 / 29 / 99$ & P. T. Day & R3-11 & \\
\hline & & E. W. Gerber & R3-11 & \\
\hline & & D. P. Kimball & R3-11 & \\
\hline & & W. C. Miller & R3-11 & \\
\hline 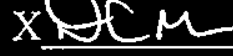 & $x 6130199$ & D. C. Mobley & $X 3-73$ & \\
\hline & & R. P. Ruth & R3-11 & \\
\hline \multirow{18}{*}{$\times \not M M X$} & & D. W. Siddoway & $X 3-85$ & \\
\hline & $\times 6 / 24 / 99$ & M. H. Schorzman & $X 3-73$ & \\
\hline & & J. D. Thomson & R3-86 & \\
\hline & & D. J. Watson & X3-79 & \\
\hline & & J. H. Wicks & X3-71 & \\
\hline & & M. J. Wiemers & R3-11 & \\
\hline & & R. B. Willard & R3-11 & \\
\hline & & NHW LB/File (2) & $\mathrm{R} 3-11$ & $\mathrm{X}$ \\
\hline & . & SNF Project Files & $\mathrm{R} 3-11$ & $X$ \\
\hline & & \multirow{2}{*}{\multicolumn{3}{|c|}{$\begin{array}{l}\text { U. S. Department of Energy } \\
\text { Richland Operations Office }\end{array}$}} \\
\hline & & & & \\
\hline & & J. M. Augustenborg & $S /-41$ & \\
\hline & & T. E. Davisson & $57-41$ & $X$ \\
\hline & & J. M. Escamillo & S7-41 & \\
\hline & • & R. G. Holt & S7-41 & \\
\hline & & P. G. Loscoe & S7-41 & $\mathrm{X}$ \\
\hline & & C. A. Rodriguez & $S 7-41$ & \\
\hline & & S. A. Sieracki & A7-80 & \\
\hline
\end{tabular}

